\title{
Edible Films and Coatings as Food-Quality Preservers: An Overview
}

\author{
Elsa Díaz-Montes ${ }^{1}$ (D) and Roberto Castro-Muñoz ${ }^{2, *(\mathbb{D})}$ \\ 1 Unidad Profesional Interdisciplinaria de Biotecnología, Instituto Politécnico Nacional, Av. Acueducto s/n, \\ Barrio La Laguna Ticoman, Ciudad de México 07340, Mexico; elsadimo123@gmail.com \\ 2 Tecnologico de Monterrey, Campus Toluca, Avenida Eduardo Monroy Cárdenas 2000, \\ San Antonio Buenavista, Toluca de Lerdo 50110, Mexico \\ * Correspondence: food.biotechnology88@gmail.com or castromr@tec.mx
}

Citation: Díaz-Montes, E; Castro-Muñoz, R. Edible Films and Coatings as Food-Quality Preservers: An Overview. Foods 2021, 10, 249. https://dx.doi.org/10.3390/ foods10020249

Received: 17 November 2020 Accepted: 9 December 2020 Published: 26 January 2021

Publisher's Note: MDPI stays neutral with regard to jurisdictional claims in published maps and institutional affiliations.

Copyright: (C) 2021 by the authors. Licensee MDPI, Basel, Switzerland. This article is an open access article distributed under the terms and conditions of the Creative Commons Attribution (CC BY) license (https: / / creativecommons.org/ licenses/by/4.0/).

\begin{abstract}
Food preservation technologies are currently facing important challenges at extending the shelf-life of perishable food products (e.g., meat, fish, milk, eggs, and many raw fruits and vegetables) that help to meet the daily nutrient requirement demand. In addition, food preservation has gone beyond only preservation; the current techniques are focused on the fulfillment of two additional objectives, the suitability of the used processes and generation of environmentally friendly products with non-presence of any side effect on health. Moreover, they are also looking for additional nutritional properties. One of these preservation protocols deals with the use of edible films and coatings. Therefore, this review shows an overview of synthetic materials (e.g., glass, aluminum, plastic, and paperboard), as well as the regulations that limit their application in food packaging. Further, this review releases the current-state-of-the-art of the use of films and edible coatings as an alternative to conventional packaging, providing the main features that these biodegradable packaging should meet towards specific uses for the conservation and improvement of various food products. Herein, particular attention has been paid to the main used components (e.g., biopolymers, additives, bioactive, and probiotic components), manufacturing methods (for edible films or coatings) and their application to specific products. In addition, an outlook of the application of edible films and coatings as quality indicators of perishable products is shown.
\end{abstract}

Keywords: polysaccharides; lipids; proteins; edible films; edible coatings; conservation; quality; foods

\section{Introduction}

The packaging is likely the most important method for food preservation due to protects, preserves and provides the needed information about the product, while allows the product commercialization and distribution [1,2]. The packaging's characteristics depend on the food product that is desired to be protected. To date, different materials have been employed as packaging materials, such as paper, cardboard, metal, glass, plastic, among others [3]. However, it is likely that this traditional preservation method is the one that produces large quantities of urban solid wastes (USW). For instance, according to the most recent data (in 2018) provided by the Ministry of Environment and Natural Resources (SEMARNAT) of Mexico, production of about 102,895 USW ton per day is generated, which corresponds to paper, cardboard, glass, and some metals (aluminum). Figure 1 illustrates the percentages that correspond to each material [4]. Despite the campaigns promoted by the Secretary of the Environment (SEDEMA) regarding integral waste management, only $10 \%$ of the total USW is recycled $[4,5]$. Therefore, most of the packaging materials have unique use before being discarded. 

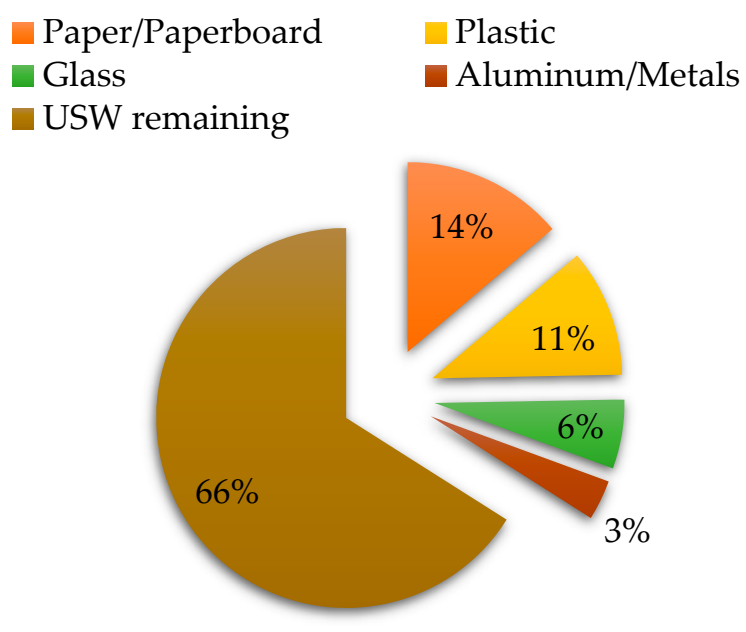

Figure 1. Distribution of packaging materials as part of the generation of urban solid waste (USW) [4].

On the other hand, companies, which prefer to recycle the materials, are also facing the issue of classification since most of the packages are constituted by a mixture of materials with different characteristics. At this point, the recovery, selection, cleaning and reprocessing of materials make the recycling a complicated and expensive task [2]. For this reason, renewable raw materials have been deeply explored in recent years at aiming to minimize pollution problems through alternative biodegradable packaging [6]. In this way, packaging based on biodegradable materials have emerged and evolved as an option to replace traditional materials that cannot be recycled. Such biodegradable materials can protect the product while their production, recycling, and degradation are relatively easy [1]. Generally, most of the biodegradable packaging implies the use of environmentally friendly polymeric materials aiming for the preservation of quality and extending the selftime of the minimally processed products, such as fruits and vegetables $[7,8]$. Herein, the goal of this review paper is to provide an overview of the current-state-of-the-art of the use of edible films and coatings in different foods, paying special attention to the main used components (e.g., biopolymers, additives, bioactive, and probiotic components), manufacturing methods (for edible films or coatings) and their application to specific products. Moreover, this review provides the main features that biodegradable packaging should meet to be considered as edible films and coatings towards specific uses for the conservation and improvement of various food products.

\section{Food Packaging and its Role in Food Preservation}

Once foods are minimally or fully processed, the packaging is becoming the most important step due to allows their transportation from the factories to the point of sale or distribution. Thereby, such material contributes to maintain most of the physicochemical, functional, and organoleptic characteristics of the food [2,9]. In addition to this, the packaging must not interact with the product and protect it from external damage of chemical, physical, and biological type [2]. Chemical damage includes exposure to gases, moisture and light; physical damage refers to any damage caused by any shock or vibration; and biological damage is caused by the action of pathogens, insects, animals, or the senescence of the food itself [9]. The next section addresses the overview of the different food packaging materials, including plastic, metal, glass, paper, among others, towards the preservation of the foods.

\subsection{Conventional Food Packaging Materials}

Plastic is the most known packaging material, and many petrochemical-based materials are currently used due to their availability at a relatively low cost. However, environmental conservation regulations have strongly restricted their use as packaging materials since they are not fully recyclable or biodegradable [10]. In the case of paper, it is 
used as packaging due to the fact that it comes from a biodegradable matter; nevertheless, being in contact with food loses its physical appearance and prevents its protection. This is one of the main reasons to combine it with other materials, such as plastic and aluminum. Unfortunately, paper loses its biodegradable effect and the feature to be recycled [11].

Glass is likely the oldest material used as packaging. It is chemically inert and odorless making its use very wide. Nowadays, the packages based on the glass are thin and resistant to sterilization treatments at high temperatures and pressures [9]. Metals are the most versatile material in all forms of packaging since it is highly resistant and fully recyclable. Aluminum and steel are found as the most common metals. Aluminum has the advantage of being moldable to the product, while steel is only used as a container. In general, metal gaskets protect against moisture, air, odors, and microorganisms [9].

Table 1 summarizes the type of packaging based on such materials and their advantages and disadvantages as barrier types. Their selection depends specifically on the type of food or product to be protected. For example, jellies and sauces without any preservatives are mostly packed in glass containers because the protection against biological agents is almost ensured, allowing their preservation for a long time [9]. The canned products are mostly packaged in aluminum containers to avoid odor exchange and microbial contamination [2,9]. While products of fast consumption due to their short life, such as milk, bread and cookies, are usually packed in plasticized cardboard, being sufficient for protection in short times [2].

Table 1. Some advantages, disadvantages of the conventional packing materials $[2,9]$.

\begin{tabular}{ccccc}
\hline Packing Material & Advantage & Disadvantage & Barrier Type & Food Type \\
\hline Glass & Recyclable materials & Susceptible to breakage & $\begin{array}{c}\text { Protection for chemical and } \\
\text { biological agents, physical } \\
\text { damage, and odors }\end{array}$ & $\begin{array}{c}\text { Sodas pop } \\
\text { Jellies } \\
\text { Sauces }\end{array}$ \\
Metal & Recyclable materials & $\begin{array}{c}\text { Expensive compared to } \\
\text { other packing materials }\end{array}$ & $\begin{array}{c}\text { Protection for chemical and } \\
\text { biological agents, physical } \\
\text { damage, and odors }\end{array}$ & $\begin{array}{c}\text { Preserves } \\
\text { Juices } \\
\text { Fish }\end{array}$ \\
\hline Plastic & Cheap materials & $\begin{array}{c}\text { Association with other } \\
\text { packaging materials }\end{array}$ & Permeability of gases and vapors & $\begin{array}{c}\text { Sodas pop } \\
\text { Water } \\
\text { Bread }\end{array}$ \\
\hline Paperboard & Biodegradable materials & $\begin{array}{c}\text { Association with other } \\
\text { packaging materials }\end{array}$ & Protection from physical \\
damage, abrasions and crushing & $\begin{array}{c}\text { Milk } \\
\text { Cookies } \\
\text { Eggs }\end{array}$ \\
\hline
\end{tabular}

\subsection{Food Packaging Laws and Regulations}

There are laws that regulate the quality control of packaging in terms of their interaction with the food products (packaging-product relationship). These regulations are complex due to the diversity of specific packaging, variety of materials (such as paper, glass, and plastic), presentations (e.g., boats, boxes, and bags), aggregates of presentations (e.g., inks, adhesives, and seals) and the characteristics of the food products (e.g., moisture, fat or alcohol content, $\mathrm{pH}$, and freshness) [12]. The Food and Drug Administration (FDA) has mentioned that any possible contamination packaging-product may be associated with the recycling of the packaging material, exposed to any harmful substance from packaging solutions, or generated during treatments (e.g., thermal or chemical). Likewise, such substances can be contained for a long time in reused packaging material [13]. Although, there are standards that specify the maximum acceptable levels of chemical contaminants being in contact with the foods [13]. Herein, the packaging should meet five basic requirements to be commercially available: (i) the packaging should not display any human health risk, (ii) the packaging should not change the physicochemical composition of the food, (iii) the packaging should not change the organoleptic features of the food, (iv) the packaging 
must be manufactured and treated according to good manufacturing practices, and (v) the packaging must not present misleading information about the contained product [12].

On the other hand, the legislation established by the International Organization for Standardization (ISO) also deals with regulations that involve the production, distribution, and use of packaging materials, such as ISO 18604:2013(E). Such regulations establish the requirements that the different food packaging materials should meet in order to be collected, processed, and recycled as a new feedstock [14]. Although these norms help to control the quality of food products through adapting the packing materials; there are also regulations that rule the environmental aspect of the waste production from packaging [15], which have restricted the use of packages that contribute directly or indirectly to the pollution of the flora and fauna. However, the total elimination of packaging is perhaps impossible; this is due to the food needs always feasible protection during its distribution that allows them to be maintained until consumption [9]. Whereas the European Union legislation covers all materials that may be in direct or indirect contact with food, for example, production machinery, kitchen utensils involved in filling and containers and packaging used for distribution (regulation EC 10/2011). This regulation includes specific specifications on the use of active and intelligent packaging (regulation EC 1935/2004) since they can only release substances accredited as food additives and must be accompanied by a declaration of conformity [16]. For this reason, by considering specific products, edible films and coatings have become a latent and promising alternative to preserve and even enhance the quality of the foods during their processing and storage [17]. Thereby, the following sections of this review provide a critical overview in applying edible films and coatings for food preservation, addressing the following aspects: main components and their properties, feasible protocols and techniques for coating fabrication, and applications and the most recent advances in the field.

\section{Edible Films and Coatings as Packing Materials}

\subsection{Characteristics of Edible Films and Coatings}

An edible film or coating is any material with a thickness of less than $0.3 \mathrm{~mm}$ [18], which is formed from a combination of biopolymers and different additives (Section 3.2) dispersed in aqueous media [19-21]. Some authors use the terms of edible film and coating interchangeably; however, others consider that there is a distinction due to the techniques of incorporation into the food product [22]. The edible coating is formed directly on the food, while the edible film is previously made and then adhered to the product $[22,23]$. Despite this, in both cases, rigid matrices with similar characteristics are formed $[6,24]$.

Figure 2 illustrates the main characteristics that edible films and coatings can present: (i) protection against UV light [17]; (ii) transport of solutes (e.g., salts, additives, and pigments), water vapor, organic vapors (e.g., aromas and solvents), and gases (e.g., oxygen, carbon dioxide, nitrogen, and ethylene) between food and the atmosphere [17,25]; (iii) barrier against mechanical damage (e.g., dents or cuts) [22]; (iv) increase the shelf-life of the product [25]; (v) bioactive components (e.g., antioxidants) [26,27]; (vi) antimicrobial effect against bacterial reproduction and fungal contamination (e.g., silver nanoparticles) [26,28]; (vii) healthy microorganisms (e.g., probiotics) that confer benefits to the consumer; and (viii) biodegradable natural materials [22]. 


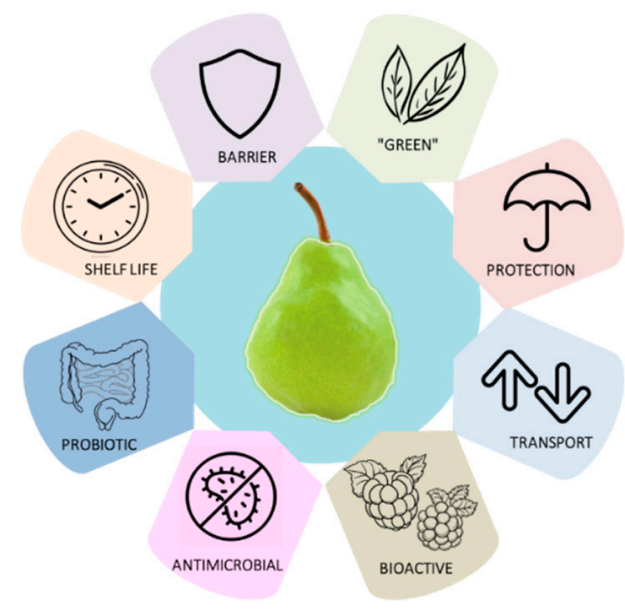

Figure 2. Scheme illustrating the main characteristics of edible films and coatings.

\subsection{Materials of Edible Films and Coatings}

In addition to similar characteristics (Section 3.1), edible films and coatings are often evaluated for their mechanical properties, such as elasticity modulus (EM), elongation at break (E), and tensile strength (TS) [29-31], which refer to their elasticity and rigidity, and the force necessary to break them [32]. Further, they display similar mass transfer phenomena (i.e., permeation, adsorption, and diffusion), which is related to the transport of solutes between food and the atmosphere [29]. However, both mechanical properties and mass transfer phenomena are influenced by the type of material and manufacture protocol that allows the generation of different structures of biopolymeric matrices [33-36]. Table 2 enlists the most used biopolymers and additives in the production of edible films and coatings, together with their properties and functionality in packing.

Table 2. Main materials used and functionality in the manufacture of edible films and coatings [6,37-47].

\begin{tabular}{|c|c|c|c|}
\hline Materials & Examples & Properties & Function in Edible Films and Coatings \\
\hline \multicolumn{4}{|c|}{ Biopolymers } \\
\hline Polysaccharides & $\begin{array}{l}\text { Starch } \\
\text { Cellulose } \\
\text { Pectin } \\
\text { Gums } \\
\text { Chitosan } \\
\text { Agar } \\
\text { Alginate } \\
\text { Dextran }\end{array}$ & $\begin{array}{l}\text { Thickeners } \\
\text { Gellants } \\
\text { Emulsifiers } \\
\text { Stabilizers } \\
\text { Coating }\end{array}$ & They form the base structure of a solid polymer matrix. \\
\hline Proteins & $\begin{array}{l}\text { Gelatin } \\
\text { Casein } \\
\text { Whey protein }\end{array}$ & $\begin{array}{l}\text { Gellants } \\
\text { Thickeners } \\
\text { Stabilizers } \\
\text { Foaming }\end{array}$ & $\begin{array}{l}\text { They help in the transport of antimicrobials and antioxidants. } \\
\text { They control the transport of gases (mainly oxygen). }\end{array}$ \\
\hline Lipids & $\begin{array}{l}\text { Waxes } \\
\text { Paraffin } \\
\text { Glycerides }\end{array}$ & $\begin{array}{l}\text { Protectors } \\
\text { Coatings }\end{array}$ & $\begin{array}{l}\text { They help to avoid drying or dehydration of the edible film } \\
\text { providing flexibility. }\end{array}$ \\
\hline \multicolumn{4}{|c|}{ Additives } \\
\hline Plasticizers & $\begin{array}{l}\text { Glycerol } \\
\text { Aloe } \\
\text { Resins }\end{array}$ & $\begin{array}{l}\text { Viscosity } \\
\text { Resistance } \\
\text { Flexibility }\end{array}$ & $\begin{array}{l}\text { They decrease the intermolecular force and the melting } \\
\text { temperature in the mixture. } \\
\text { They also modify the viscosity and the rheological properties. }\end{array}$ \\
\hline Chaotropic agents & Polyphenols & $\begin{array}{l}\text { Destructuring agent } \\
\text { Antioxidants } \\
\text { Stabilizers } \\
\text { Fungicides } \\
\text { Herbicides } \\
\text { Fertilizers }\end{array}$ & They work as stabilizers as well as protection for the products. \\
\hline
\end{tabular}


Starch is considered the universal biopolymer for bio-packaging, which has been widely used for decades [48], due to its characteristics and gelatinization properties [29]. Alginate is another important biopolymer that displays the ability to form hydrogels and encapsulation barriers [49,50]. However, chitosan has recently attracted attention for the elaboration of edible films and coatings [51] due to their properties as a gelling agent and their chemical (it could form hydrogen bonds and hydrophobic interactions) and biological (its biocompatibility, biodegradability, and bioactivity) properties [52,53]. While other authors have selected the use of other natural components for the formulation of packaging, including proteins (e.g., collagen and protein isolates) [54,55], lipids (e.g., canola oil and cinnamon bark oil) [56,57], among other unconventional materials (e.g., smooth-hound protein and papaya puree) $[58,59]$ to produce bio-packaging with targeted characteristics.

On the other hand, the role of additives (e.g., plasticizers or stabilizers) in the formulation of edible films and coatings is to modify the mechanical properties (to ideally increase $\mathrm{E}$ and decrease TS and EM) and mass transfer phenomena $[6,29]$. Furthermore, the incorporation of antioxidant, fungicidal, or microbial additives allows obtaining bioactive bio-packaging [45,60]; which will be discussed in detail (Section 4).

\subsection{Disperse Systems Forming Edible Films and Coatings}

The biopolymeric materials used for the formulation of bio-packaging are incorporated in different ways due to their glucidic (i.e., polysaccharides), proteinic or lipidic nature; creating dispersed emulsion-type (i.e., based on lipids) or colloidal systems (i.e., based on polysaccharides or proteins) [61]. Figure 3 outlines the two types of systems that can be formed for the generation of edible films and coatings.

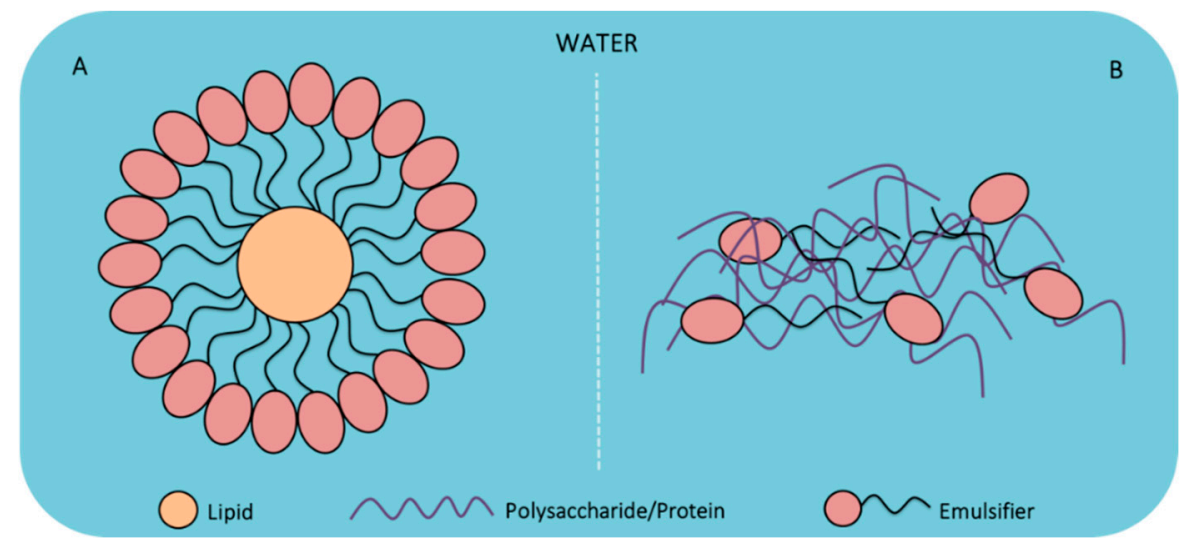

Figure 3. Main types of dispersed systems generated based on biopolymers, (A) emulsion oil/water $(\mathrm{o} / \mathrm{w})$ and $(\mathbf{B})$ colloidal dispersions.

Emulsions are systems composed of liquid or semi-liquid substances that are immiscible to each other, e.g., an oil and aqueous phase that can be merged by means of an emulsifying agent. The emulsifying agent generally possesses a hydrophilic and a hydrophobic zone, displaying an affinity to polar and non-polar sites [26,62]. Thus, emulsions can be classified in two types depending on the proportions of their phases, e.g., oil/water $(\mathrm{o} / \mathrm{w})$ or water/oil $(\mathrm{w} / \mathrm{o})$ because the dispersed phase corresponds to the second component, being in lower concentration in the emulsion [61,63]. In the formulation of edible films and coatings, the o/w systems are preferred (Figure 3A) since they are thermodynamically more stable and they can dissolve lipophilic antimicrobial components (e.g., plant essential oils) and bioactive components (e.g., fatty acids, carotenoids, antioxidants, phytosterols, or quinones) [26].

Colloid systems are polymeric systems that are made up of polysaccharides or proteins dissolved in an aqueous phase [61]; they form a dense matrix that can protect active components (e.g., antioxidant and antimicrobial agents) [64] and allow their controlled release 
in the matrix [65]. Due to the hydrophilic nature of polysaccharides and proteins, colloidal systems are mostly used for the development of edible films and coatings since they can transport and protect a large number of molecules that act as additives (e.g., essential oils) $[66,67]$ and probiotics (e.g., lactic acid bacteria) $[68,69]$. Colloidal systems do not form a matrix with an ordered grouping in their polymeric components (Figure $3 \mathrm{~B}$ ) due to the fact that different types of interactions (e.g., ionic, hydrogen bridges, or electrostatic interaction) can be produced according to the type of biomaterial (i.e., protein or polysaccharide); therefore, they tend to which generate matrices with varied characteristics [70,71].

The dispersed systems must be incorporated/coated into the product to dry (or vice versa) and subsequently generate a rigid matrix that will act as an edible film or coating. This will strictly depend on the type of application protocol [72]. The most used application techniques are (A) dipped, (B) spread, (C) sprayed, and (D) wrapped, as illustrated in Figure 4 . The edible coating formulations are added and dried directly on the surface of the food (Figure $4 \mathrm{~A}-\mathrm{C}$ ), while the edible film formulations are poured into a mold and dried to later be incorporated into the product (Figure 4D).

A
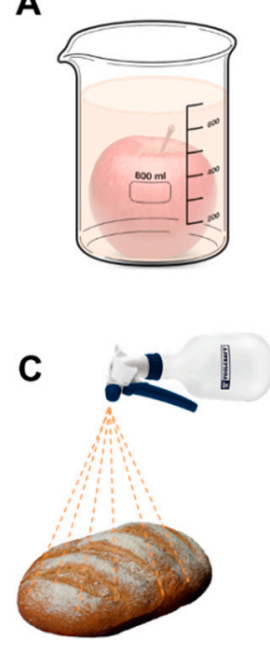

B

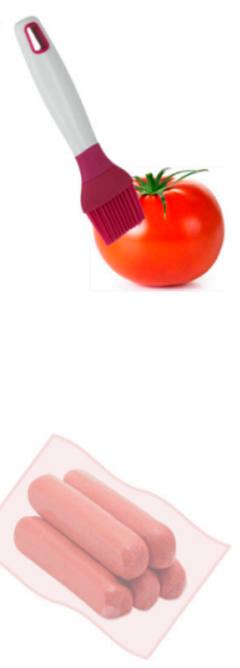

Figure 4. Main techniques used for food coating. (A) Dipped; (B) Spread; (C) Sprayed; (D) Wrapped.

\section{Recent Advances in Edible Films and Coatings}

\subsection{Edible Films as Functional Bio-Packages}

According to the definition given by Kris-Etherton et al. [73], a bioactive component is any constituent contained in small amounts in food which can display effects on the health after their consumption. Epidemiological studies have analyzed different bioactive molecules (e.g., flavonoids and phytoestrogens), which in fact have been recognized by their antioxidant, antimutagenic, anti-inflammatory, anti-cancer, apoptotic, and anti-cholesterol effects [74-79]. Thus, various researches have been specifically focused on incorporating a wide variety of these bioactive compounds into edible films, as enlisted in Table 3. 
Table 3. Edible films containing different types of bioactive compounds and natural extracts.

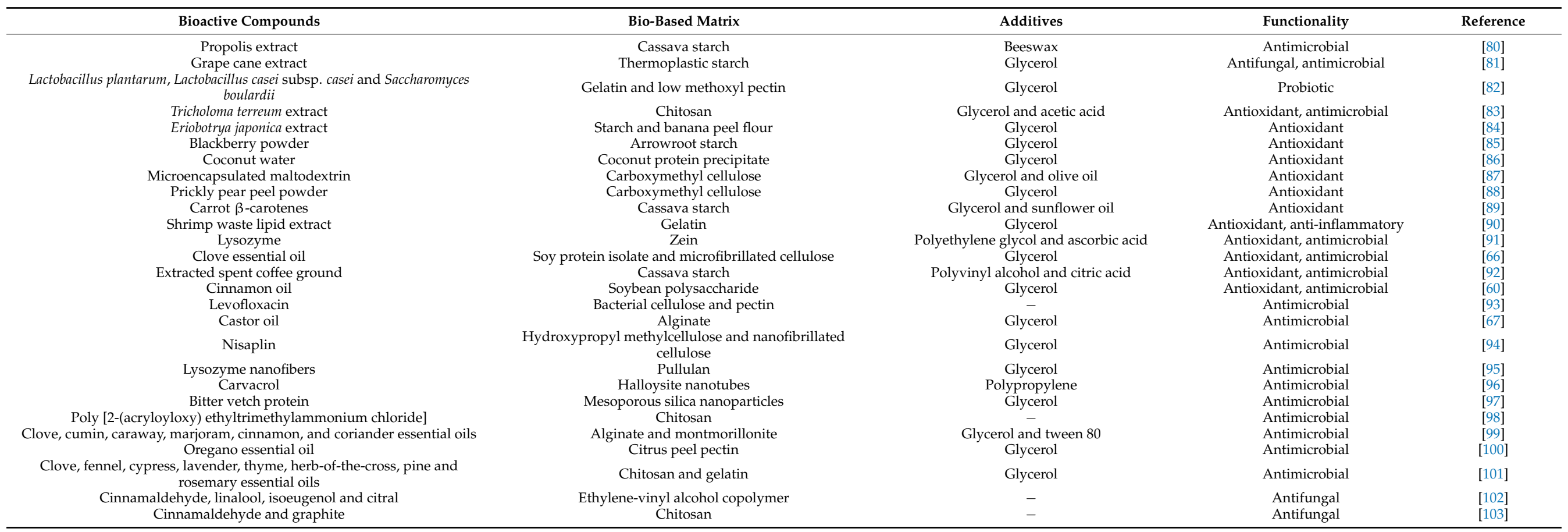


For example, several authors have evaluated the antioxidant capacity of edible films with phenolic compounds extracted from various sources [85,86,89]. Nogueira et al. [85] determined that the antioxidant activity of blackberry powder is related to its anthocyanin content, and it was maintained when added to arrowroot starch edible films; furthermore, the water solubility, water vapor permeability, TS and E properties were improved with the addition of the powder, while the color and flavor characteristics of the blackberries remained. Rodsamram and Sothomvit [86] elaborated edible films based on coconut protein and coconut water, which presented antioxidant activity given by phenolic compounds of coconut; also, the brown coloration of the edible films exerted a barrier towards UV light. While Assis et al. [89] extracted and encapsulated $\beta$-carrot carotenes in a cassava starch matrix, resulting in edible films with antioxidant activity and improved solute transport. In these studies, the antioxidant effect was given by the action of bioactive substances that cause a significant delay in the oxidation of the substrate, and also the inhibitions of reactions involving free radicals [104].

Other authors have extracted oils from various sources, which have displayed antimicrobial activity; for example, Abdel Aziz et al. [67] incorporated castor oil to an alginate matrix to generate edible films with an inhibitory effect against Staphylococcus aureus, Bacillus subtilis, Salmonella typhi, and Escherichia coli. The greatest effect was noticed when increasing the concentration of castor oil due to an increase in the hydrophilic character of the edible films by the hydroxyl groups of edible oil, which easily dissolve the membrane cell and provoke the uncontrolled transport of substances into the bacteria $[105,106]$. Alvarez et al. [100] generated edible films of citrus peel pectin with oregano essential oil that exerted an effect against Chromobacterium violaceum by inhibiting cell communication due to the action of oregano essential oil [107]. Similarly, Alboofetileh et al. [99] used different essential oils (i.e., clove, cumin, caraway, marjoram, cinnamon, and coriander essential oils) in edible films based on alginate and montmorillonite. Thanks to the presence of the oils, the films showed antimicrobial activity against Escherichia coli, Staphylococcus aureus, and Listeria monocytogenes [99]; however, marjoram essential oil presented the highest inhibition due to the control of cell growth; in addition, the biopolymeric matrix formed between alginate and montmorillonite controlled the release of the oils, maintaining continuous inhibitory effect [108].

Some other biologically active compounds, such as organic acids (e.g., acetic acid, benzoic acid, sodium benzoate, and sorbic acid), peptides (e.g., nisin), and enzymes (e.g., lysozyme), have been incorporated into edible films and coatings for their antimicrobial action [109]. The antifungal effect and low toxicity (for the consumer) of natural components, such as citrus plants (e.g., lemon) or essential oils (e.g., cinnamon, clove and oregano essential oils), have also been demonstrated [110]. For example, the increasing of cinnamaldehyde concentration in chitosan-graph-based edible films has proven the antifungal properties against Penicillium italicum and Rhizopus stolonifera [103]. In addition, additives (i.e., cinnamaldehyde) improved the mechanical properties in terms of EM, E and TS testing. Tarazona et al. [102] also evaluated cinnamaldehyde and other additives (i.e., linalool, isoeugenol and citral) in edible films of ethylene-vinyl alcohol copolymer. The results showed different antifungal activities against Aspergillus steynii and Aspergillus tubingensis, but the effect was greater with the presence of cinnamaldehyde since there was a total inhibition of fungi [102].

Bioactive components are able to concurrently display several properties, which may produce a synergistic effect; for example, Ounkaew et al. [92] and Wei et al. [91] analyzed the antioxidant and antimicrobial capacity of two different edible films with incorporated organic acids. Ounkaew et al. [92] manufactured edible films based on cassava starch, extracted spent coffee ground and citric acid; which exhibited antioxidant capacity and inhibitory effect against Escherichia coli and Staphylococcus aureus given by the synergistic effect between the biopolymer and additives, together with the increasing content of citric acid. While Wei et al. [91] embedded lysozyme enzyme and ascorbic acid in zein-based edible film. The authors reported that higher enzyme concentrations resulted in better 
antimicrobial properties against Listeria innocua and Micrococcus lysodeikticus), while the increase of organic acids improved the antioxidant capacity of the edible films [91]; in addition, a synergistic effect in flexibility and mechanical properties was seen between zein, lysozyme and ascorbic acid.

\subsection{Coatings as Pathogen Inhibitors in Food Models}

Most of the characteristics of edible films and coatings are relevant; however, the biological protection of food is one of the most important since it directly affects the shelflife of the product [111]. Therefore, it is necessary to inhibit or eliminate bacterial or fungal microorganisms (as well as their derivatives) that can cause or accelerate putrefaction in food due to the action of their enzymes and by-products produced from their metabolism (e.g., gases) [112].

The lactic acid bacteria are generally recognized as safe (GRAS) and there are many kinds of research that show the beneficial effects when acting in the consumer's gastrointestinal tract (Figure 5) [113]. Thus, some authors have also focused on evaluating the inhibitory effect of edible films with Lactic acid bacteria (LAB) and fungi activities against pathogenic microorganisms applied in food models, as summarized in Table 4.

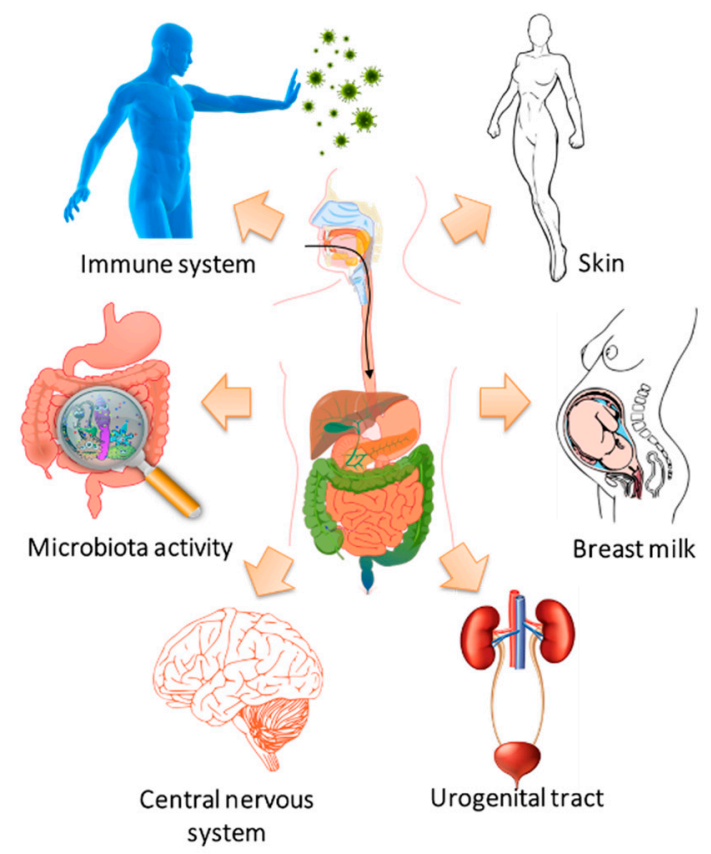

Figure 5. Schematic representation of the health benefits after probiotic consumption [113].

For example, Aloui et al. [117] inoculated the Wickerhamomyces anomalus in two different edible films based on alginate and locust bean gum, and subsequently covered oranges finding that the bacteria had greater stability in the alginate matrix; in addition, alginate edible film managed to inhibit Penicillium digitatum and kept the fruit viable over 13 days. Parafati et al. [116] also inoculated Wickerhamomyces anomalus, Metschnikowia pulcherrima and Aureobasidium pullulans in mandarins coated with edible carob gum edible films; the findings show a greater inhibitory effect with Metschnikowia pulcherrima against Penicillium digitatum and Penicillium italicum. 
Table 4. Coatings with microorganism against pathogens applied in food models.

\begin{tabular}{|c|c|c|c|c|c|}
\hline Biopolymeric Matrix & Additives & Food Type & Microorganisms & Inhibited Pathogens & Reference \\
\hline Alginate & Glycerol & Ham slices & $\begin{array}{c}\text { Lactobacillus plantarum and Lactobacillus } \\
\text { pentosus }\end{array}$ & $\begin{array}{l}\text { Brochothrix thermosphacta, } \text { Pseudomonas } \\
\text { spp., Enterobacteriaceae, yeasts/molds } \\
\text { and Listeria monocytogenes }\end{array}$ & [114] \\
\hline $\begin{array}{l}\text { Hydroxypropylmethyl cellulose, sodium caseinate, pea } \\
\text { protein and corn starch }\end{array}$ & Glycerol & Grapes & Candida sake & Botrytis cinerea & [115] \\
\hline Locust bean gum & - & Mandarins & $\begin{array}{l}\text { Wickerhamomyces anomalus, Metschnikowia } \\
\text { pulcherrima and Aureobasidium pullulans }\end{array}$ & $\begin{array}{c}\text { Penicillium digitatum and Penicillium } \\
\text { italicum }\end{array}$ & [116] \\
\hline Alginate and locust bean gum & Glycerol & Oranges & Wickerhamomyces anomalus & Penicillium digitatum & [117] \\
\hline Agar & Glycerol and green tea extract & Hake fillets & $\begin{array}{c}\text { Lactobacillus paracasei and Bifidobacterium } \\
\text { lactis }\end{array}$ & $\begin{array}{c}\text { Shewanella putrefaciens and Photobacterium } \\
\text { phosphoreum }\end{array}$ & [118] \\
\hline Alginate and corn starch & Glycerol & Coated biscuits & Lactobacillus plantarum & $\begin{array}{l}\text { Salmonella, Escherichia coli and } \\
\text { Streptococcus thermophilus }\end{array}$ & [119] \\
\hline Starch and alginate & Glycerol & Cold-smoked salmon covered & Carnobacterium maltaromaticum & Listeria monocytogenes & [120] \\
\hline Alginate & $\begin{array}{c}\text { Glycerol, palmitic acid and } \\
\beta \text {-cyclodextrin }\end{array}$ & Strawberries & Cryptococcus laurentii & Mold & [121] \\
\hline
\end{tabular}


Other studies of microorganisms incubate in coatings for the control of pathogenic fungi, as reported by Marín et al. and Fan et al. [115,121]. The first study evaluated several edible films (i.e., hydroxypropylmethyl cellulose, sodium caseinate, pea protein and corn starch) to serve as a support for Candida sake and later coat grapes to protect against Botrytis cinerea [115]; although all biopolymers were adequate to inhibit the pathogen and maintain the survival of Candida sake, the authors recommended the use of sodium caseinate and corn starch since they represent the lowest cost. In the second study, Fan et al. [121] used alginate edible film containing Cryptococcus laurentii to coat strawberries, the authors reported that the microorganism remained viable, and the edible films significantly reduced mold and improved the quality and physical appearance of the fruits.

\subsection{Coatings as Probiotic Carriers in Food Models}

Probiotics are a type of bioactive compounds with specific health benefits [122]. According to the definition in 2002 given by the Food and Agriculture Organization of the United Nations/World Health Organization (FAO/WHO), probiotics are "live microorganisms which, when administered in adequate amounts, confer a health benefit on the host" [123]. LAB of the genus Lactobacillus have been widely studied for their probiotic properties since they play an important role in preventing the deterioration of the microbiota and in the inhibition of pathogenic microorganisms (Table 4) at the oral cavity and colon [124]. In addition, there is evidence that relates the metabolic activity of LABs with the control of bacterial pathogens and fungal agents [113]; specifically, the authors associate the inactivation of pathogens by the effect of organic acids (e.g., lactic and acetic acids), carbon dioxide, ethanol, peptide compounds, and enzymes, that are produced within LABs metabolism [125]. Other authors relate the decrease in $\mathrm{pH}$ with the inhibitory effect because it generates an environment competition between the substrates of LABs and pathogenic microorganisms $[113,126]$. For this reason, the most exhaustive studies in probiotic evaluation have been carried out in the incorporation of microorganisms in edible films and coatings, rather than on their inhibitory efficacy against external pathogens (due to contamination of the environment). Figure 5 presents an overview of the main systems and organs benefited by the consumption of probiotic microorganisms, highlighting (i) the immune system: inflammatory control is maintained; (ii) the microbiota: the proliferation of pathogenic microorganisms, such as Clostridium difficile and Helicobacter pylori, is regulated; (iii) the nervous system: brain functions are modulated; (iv) the urogenital tract: urogenital infections are fought; (v) the placenta: probiotic microorganisms are transmitted to the fetus; and (vi) the skin: allergies and atopic dermatitis is helped [113].

The main purpose of stabilizing or keeping probiotics viable is that once ingested, they can withstand the conditions of gastric juices and intestinal fluids; in this way, they can be dosed periodically to carry out their probiotic effect [72,113]. Therefore, Gbassi et al. [127] studied the viability of Lactobacillus plantarum encapsulated in alginate and subsequently introduced in an edible film of whey protein under gastrointestinal conditions $(\mathrm{pH} 1.8$ at $37^{\circ} \mathrm{C}$ ); as a result, the probiotics remained viable until $180 \mathrm{~min}$. This study is relevant due to the simplicity of the matrix and its efficiency together with the costs of alginate and whey protein [127].

Importantly, the main objective of a probiotic embedded in edible films is to study and evaluate their viability within the matrix, as well as its interaction with the coated food and its probiotic activity. Table 5 presents different studies in which edible coatings were applied to food products, monitoring the viability of the probiotics directly on the product. 
Table 5. Edible coatings-probiotics applied in food models.

\begin{tabular}{|c|c|c|c|c|c|}
\hline Biopolymeric Matrix & Additives & Probiotic Microorganisms & Food Product & Survival Time & Reference \\
\hline $\begin{array}{l}\text { Maltodextrin, alginate and } \\
\text { carboxymethyl cellulose } \\
\text { Hydroxypropylmethyl }\end{array}$ & Glycerol & Asparagus racemosus & Chevon sausages & 21 days & [128] \\
\hline $\begin{array}{l}\text { cellulose, sodium caseinate, } \\
\text { pea protein and corn }\end{array}$ & Glycerol & Candida sake & Grapes & 14 days & [129] \\
\hline Methylcellulose & Sorbitol and citric acid & Lactobacillus plantarum & Apples & 90 days & [130] \\
\hline Alginate and whey protein & Glycerol & Lactobacillus rhamnosus & Bread & 7 days & [131] \\
\hline $\begin{array}{l}\text { Carboxymethyl cellulose } \\
\text { and alginate }\end{array}$ & - & Brewer yeast & Grapes & 13 days & [132] \\
\hline Gelatin and glucose & Sorbitol and cysteine & $\begin{array}{l}\text { Lactobacillus acidophilus and } \\
\text { Bifidobacterium bifidum }\end{array}$ & Hake fish & 15 days & [133] \\
\hline Corn starch & - & Lactobacillus acidophilus & Bread & $24 \mathrm{~h}$ & [72] \\
\hline
\end{tabular}

The viability of microorganisms varies when the edible films are being individually characterized in a specific product and stored under different conditions (e.g., temperature and relative humidity). For example, Soukoulis et al. [131] evaluated the survival of Lactobacillus rhamnosus in an alginate/whey protein matrix that covered bread. They achieved to maintain the LAB stability for seven days at $25^{\circ} \mathrm{C}$. Compared with their previous study [131], the authors found out that the viability time of Lactobacillus decreased considerably (up to $93 \%$ ) when the bread was stored at $4{ }^{\circ} \mathrm{C}$; but the bacteria viability increased up to 99 days when the matrix was not applied on the bread [134].

The difference in viability time of Lactobacillus plantarum can also be compared when stored and treated under different conditions; as reported by Tavera-Quiroz et al. [130] who incorporated Lactobacillus plantarum in a methylcellulose matrix to coat apple baked snacks and maintain their viability up to 90 days in simulated in vitro gastric conditions (two stages: $\mathrm{pH} 2.5$ and 7.5 , and $37^{\circ} \mathrm{C}$ ). Gbassi et al. [127] used a whey protein matrix and similar gastric conditions to Tavera-Quiroz et al. [130], maintaining the Lactobacillus plantarum viability for $180 \mathrm{~min}$.

In particular, López De Lacey et al. [133] pointed out the importance of conserving fresh products, such as fish, since they are highly perishable products and susceptible to the development microorganisms and contamination $[12,118]$. The authors were able to extend the shelf-life of Hake fish up to 15 days at refrigerated conditions $\left(4^{\circ} \mathrm{C}\right)$ [133], at this point, Lactobacillus acidophilus and Bifidobacterium bifidum were deposited in a coating of gelatin, sorbitol, and cysteine.

\subsection{Edible Films and Coatings as Food Preservatives}

Currently, the food industries have a duty to offer to the consumers fresh, pleasant, good quality food with beneficial properties for health [8]. However, the challenge of meeting consumer demands is very demand since there is no food that can remain in optimal conditions and maintain its properties permanently due to the natural deterioration generated by chemical, and biochemical reactions and physical changes [135]. Figures 6 and 7 illustrate the different biochemical and physical defects developed in foods, respectively. Commonly, observed spoilage changes include unpleasant odors, rancidity, darkening, softening of the texture, and loss of nutrients and vitamins. 


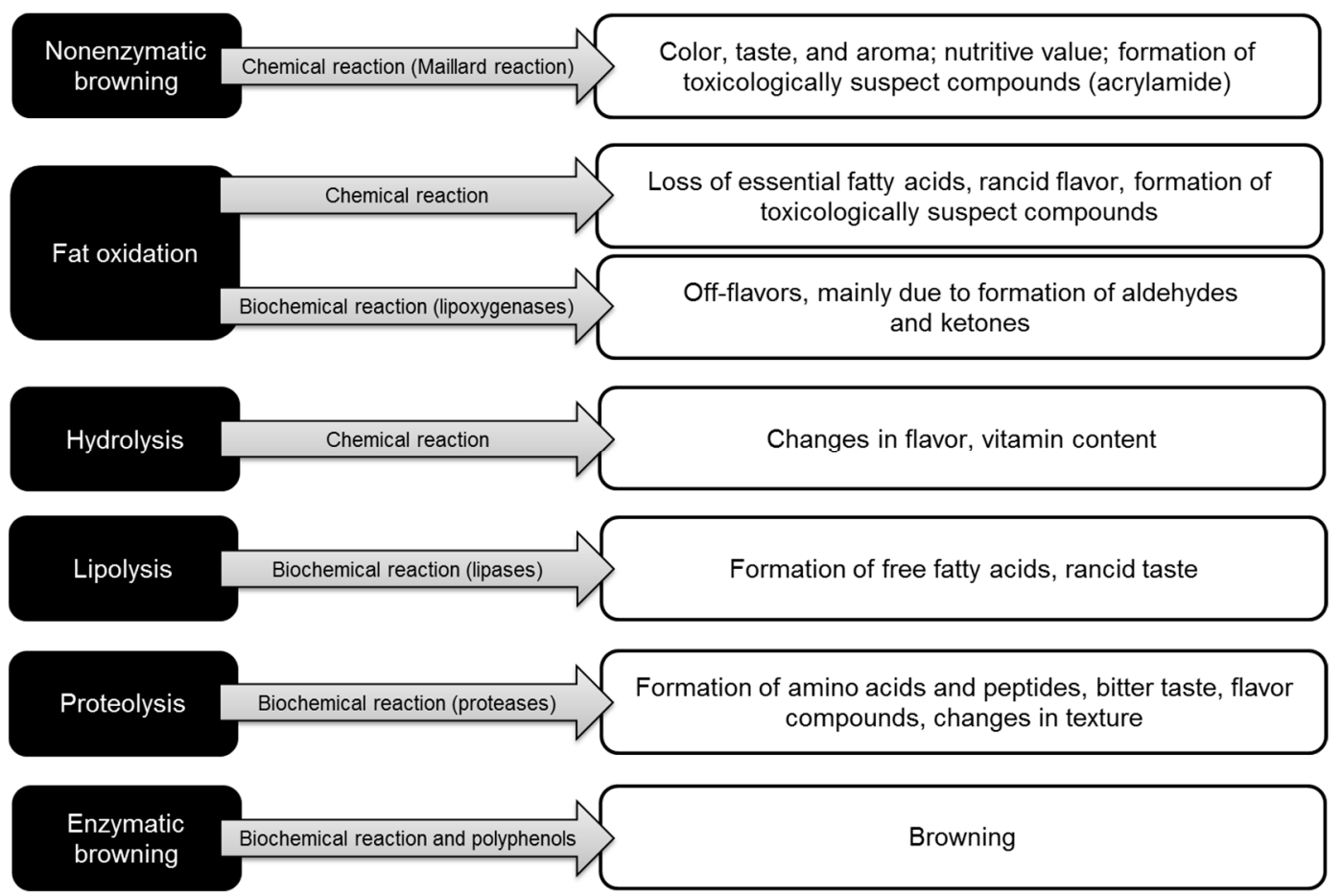

Figure 6. Chemical/biochemical reactions in foods affecting their quality [135].

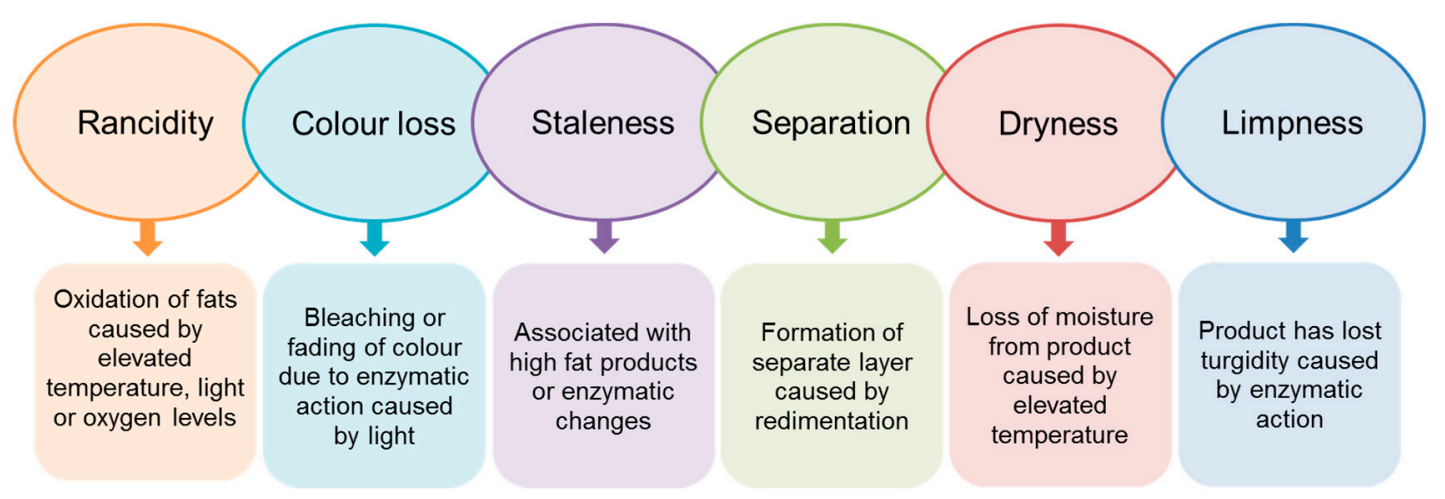

Figure 7. Non-microbial spoilage physical defects in foods [136].

Food spoilage is influenced by oxygen availability, temperature, relative humidity, water content, and $\mathrm{pH}$ [137]. For this reason, besides the characteristics of the edible films and coatings themselves, it is of great interest to maintain the characteristics of the food, including: (i) preservation of microbiological parameters in accordance with established laws; (ii) preservation of nutritional content; and (iii) preservation of physical and sensory characteristics (e.g., smell, taste, and texture); which together extend the shelf-life of the product [136].

Table 6 reports different development works aiming at extending the shelf-life of plenty fruits, vegetables, animal, and dairy products; where the edible film/coating influenced positively the chemical, biochemical and physical parameters, minimizing the food spoilage, and thus increased the shelf-life of the food product. 
Table 6. Edible films and coatings applied in food models.

\begin{tabular}{|c|c|c|c|c|c|}
\hline Food Application & Biopolymeric Matrix & Additives & Coating Technique & Positive Results & Reference \\
\hline \multicolumn{6}{|c|}{ Fruits } \\
\hline Figs & Chitosan & $\begin{array}{l}\text { Acetic acid, canola oil, } \\
\text { cinnamon essential oil and } \\
\text { Rosselle extract }\end{array}$ & Spread & $\begin{array}{c}\text { Antioxidant capacity was preserved, color change } \\
\text { was delayed and Alternaria alternata growth } \\
\text { was inhibited }\end{array}$ & [138] \\
\hline Bell pepper & Chitosan & $\begin{array}{l}\text { Acetic acid, canola oil, } \\
\text { glycerol and } \\
\text { chitosan } / \alpha \text {-pinene } \\
\text { nanoparticles }\end{array}$ & Spread & $\begin{array}{l}\text { Flavonoids and antioxidant capacity were not } \\
\text { modified and Alternaria alternata growth got slow. }\end{array}$ & [139] \\
\hline \multirow{2}{*}{ Papaya } & Papaya puree and alginate & Glycerol and citric acid & Dipped & Shelf-life was extended & [59] \\
\hline & Carrageenan & Glycerol and citric acid & Dipped & Ripening was delayed and shelf-life was extended & [140] \\
\hline \multirow[t]{2}{*}{ Blueberries } & $\begin{array}{l}\text { Alginate, chitosan, apple fiber } \\
\text { and orange fiber }\end{array}$ & $\begin{array}{l}\text { Glycerol, inulin } \\
\text { and oligofructose }\end{array}$ & Dipped & $\begin{array}{l}\text { Sensory quality was improved, and shelf-life } \\
\text { was extended }\end{array}$ & [141] \\
\hline & $\begin{array}{l}\text { Chitosan, calcium caseinate, } \\
\text { alginate and semperfresh }\end{array}$ & Glycerol and tween 20 & Dipped & $\begin{array}{c}\text { Ripening was delayed and flavor, texture and visual } \\
\text { appearance were maintained }\end{array}$ & [142] \\
\hline \multirow{6}{*}{ Strawberries } & Chitosan & $\begin{array}{l}\text { Acetic acid, canola oil, } \\
\text { cinnamon essential oil and } \\
\text { Roselle extract }\end{array}$ & Wrapped & $\begin{array}{l}\text { Antioxidant capacity was increased, and shelf-life } \\
\text { was extended }\end{array}$ & [143] \\
\hline & Chitosan and beeswax & Glycerol and tween 80 & Dipped & Quality was preserved and shelf-life was extended & [144] \\
\hline & $\begin{array}{l}\text { Chitosan and } \\
\text { carotene-proteins }\end{array}$ & $\begin{array}{l}\text { Glycerol and } \\
\text { polyvinyl alcohol }\end{array}$ & & $\begin{array}{l}\text { Microbial and fungal growth were controlled, and } \\
\text { antioxidant activity was maintained }\end{array}$ & [145] \\
\hline & $\begin{array}{l}\text { Chitosan and chitosan } \\
\text { nanoparticles }\end{array}$ & $\begin{array}{l}\text { Glycerol, acetic acid and } \\
\text { propolis extract }\end{array}$ & Dipped & $\begin{array}{l}\text { Total phenols, flavonoids and antioxidant capacity } \\
\text { were increased, ripening process was not modified, } \\
\text { and sensory characteristics were not modified }\end{array}$ & [146] \\
\hline & Fish gelatin and citrus pectin & $\begin{array}{l}\text { Glycerol and hydroxytyrosol- } \\
\text { 3,4-dihydroxyphenylglycol }\end{array}$ & Dipped & $\begin{array}{c}\text { Mold growth was delayed, and shelf-life } \\
\text { was extended }\end{array}$ & [147] \\
\hline & Cassava starch & Propolis extract & Dipped & Vitamin $C$ content was promoted & [148] \\
\hline Fresh-cut jackfruit bulbs & $\begin{array}{l}\text { Xanthan, alginate and } \\
\text { gellan gum }\end{array}$ & $\begin{array}{l}\text { Glycerol and } \\
\text { 1-methylcyclopropene }\end{array}$ & Dipped & $\begin{array}{c}\text { Microbial growth was inhibited, and shelf-life } \\
\text { was extended }\end{array}$ & [149] \\
\hline Fresh-cut kiwifruit & Cactus pear mucilage & Glycerol and tween 20 & Dipped & $\begin{array}{l}\text { Visual quality and flavor were improved, and } \\
\text { shelf-life was extended }\end{array}$ & [150] \\
\hline
\end{tabular}


Table 6. em Cont

\begin{tabular}{|c|c|c|c|c|c|}
\hline Food Application & Biopolymeric Matrix & Additives & Coating Technique & Positive Results & Reference \\
\hline \multicolumn{6}{|c|}{ Fruits } \\
\hline \multirow{9}{*}{ Fresh-cut apples } & Whey protein & $\begin{array}{l}\text { Glycerol, citric acid and } \\
\text { montmorillonite clay }\end{array}$ & Wrapped & Shelf-life was extended & [151] \\
\hline & Carboxymethyl cellulose & $\begin{array}{l}\text { Glycerol, calcium and } \\
\text { acid ascorbic }\end{array}$ & Dipped & $\begin{array}{c}\text { Vitamin } \mathrm{C} \text { and antioxidant capacity } \\
\text { were maintained }\end{array}$ & [152] \\
\hline & \multirow{2}{*}{$\begin{array}{l}\text { Chitosan } \\
\text { Alginate, gellan gum, pectin } \\
\text { and apple fiber }\end{array}$} & \multirow{2}{*}{$\begin{array}{l}- \\
\text { Glycerol, ascorbic acid and } \\
\text { inulin }\end{array}$} & Dipped & Quality was enhanced & [153] \\
\hline & & & Dipped & Quality was enhanced and shelf-life was extended & {$[154]$} \\
\hline & Chocolate and milk butter & $\begin{array}{l}\text { Polyglycerol polyricinoleate } \\
\text { and ascorbic acid }\end{array}$ & Dipped & Anti-aging effect was produced & [155] \\
\hline & Olive oil and sunflower oil & Lecithin and ascorbic acid & Spread & \multirow{2}{*}{$\begin{array}{c}\text { Anti-aging effect was produced } \\
\text { Physical changes were controlled, and shelf-life } \\
\text { was extended }\end{array}$} & [155] \\
\hline & $\begin{array}{l}\text { Whey protein, soy protein, } \\
\text { alginate and carrageenan }\end{array}$ & Glycerol & Dipped & & [156] \\
\hline & $\begin{array}{l}\text { Cassava starch and } \\
\text { carnauba wax }\end{array}$ & Glycerol and stearic acid & Wrapped & Physicochemical properties were improved & [157] \\
\hline & $\begin{array}{l}\text { Soybean gum, jojoba and } \\
\text { Arabic gum }\end{array}$ & Glycerol and paraffin oil & Wrapped & Quality was maintained & [158] \\
\hline Fresh-cut pineapple & Alginate & $\begin{array}{l}\text { Glycerol, sunflower oil, } \\
\text { lemongrass essential oil, } \\
\text { calcium chloride, ascorbic } \\
\text { acid, and citric acid }\end{array}$ & Dipped & Quality was preserved and shelf-life was extended & [160] \\
\hline Fresh-cut mangoes & Alginate & $\begin{array}{l}\text { Glycerol, sunflower oil, } \\
\text { calcium chloride, ascorbic } \\
\text { acid, and citric acid }\end{array}$ & Dipped & $\begin{array}{l}\text { Browning agent was delayed, and shelf-life } \\
\text { was extended }\end{array}$ & [161] \\
\hline Fresh-cut watermelon & $\begin{array}{l}\text { Alginate, pectin and } \\
\text { calcium lactate }\end{array}$ & Glycerol & Dipped & Texture was preserved and shelf-life was extended & [162] \\
\hline \multicolumn{6}{|c|}{ Vegetables, Plants and Cereals } \\
\hline Saffron & $\begin{array}{l}\text { Maltodextrin and } \\
\text { nanocellulose }\end{array}$ & - & Spread & Physicochemical properties were improved & [163] \\
\hline Potatoes & Locust bean gum & Glycerol & Dipped & $\begin{array}{l}\text { Physical changes, microbial growth and to } \\
\text { nutritional quality were controlled }\end{array}$ & [164] \\
\hline
\end{tabular}


Table 6. em Cont.

\begin{tabular}{|c|c|c|c|c|c|}
\hline Food Application & Biopolymeric Matrix & Additives & Coating Technique & Positive Results & Reference \\
\hline \multicolumn{6}{|c|}{ Vegetables, Plants and Cereals } \\
\hline Taro corms & Chitosan and starch & Glycerol & Dipped & $\begin{array}{l}\text { Quality was enhanced, microbial growth was } \\
\text { inhibited, and shelf-life was extended }\end{array}$ & [165] \\
\hline \multirow{3}{*}{ Tomatoes } & Citrus peel pectin & Glycerol and oregano oil & Spread & $\begin{array}{l}\text { Antifungal effect was generated, and phenol } \\
\text { content and antioxidant activity were increased }\end{array}$ & [166] \\
\hline & Carnauba wax & Mineral oil & Spread & Antioxidant activity was increased & [167] \\
\hline & Chitosan and zeolite & Tween 80 and acid lactic & Dipped & Ripening was delayed & [168] \\
\hline \multirow[t]{2}{*}{ Cherry tomatoes } & \multirow{2}{*}{$\begin{array}{l}\text { Hydroxypropyl } \\
\text { methylcellulose and beeswax } \\
\text { Hydroxypropyl } \\
\text { methylcellulose and beeswax }\end{array}$} & $\begin{array}{l}\text { Glycerol, tween } 80 \text { and } \\
\text { oleic acid }\end{array}$ & Dipped & \multirow{2}{*}{$\begin{array}{l}\text { Growth fungal was reduced and physical } \\
\text { appearance was maintained } \\
\text { Growth of Botrytis cinerea was reduced and physical } \\
\text { appearance was improved }\end{array}$} & [170] \\
\hline & & Glycerol and oleic acid & Dipped & & [171] \\
\hline Shiitake mushrooms & Alginate & $\begin{array}{l}\text { Silver nitrate, sodium } \\
\text { borohydride and } \\
\text { polyvinylpyrrolidone }\end{array}$ & Dipped & Shelf-life was extended & [172] \\
\hline Spinach & $\begin{array}{l}\text { Agar, k-carrageenan, } \\
\text { and konjac }\end{array}$ & Glycerol & Wrapped & $\begin{array}{l}\text { Freshness was maintained and shelf-life } \\
\text { was extended }\end{array}$ & [174] \\
\hline White asparagus & $\begin{array}{l}\text { Sodium } \\
\text { carboxymethyl-cellulose, } \\
\text { whey protein isolate } \\
\text { and pullulan }\end{array}$ & $\begin{array}{l}\text { Sucrose fatty acid ester, } \\
\text { polyethylene glycol, sorbitol } \\
\text { and stearic acid }\end{array}$ & Dipped & Weight loss was reduced, and quality was preserved & [175] \\
\hline \multicolumn{6}{|c|}{ Animal and Dairy Products } \\
\hline \multirow[t]{2}{*}{ Sausages } & $\begin{array}{l}\text { Maltodextrin, alginate and } \\
\text { carboxymethyl cellulose }\end{array}$ & $\begin{array}{c}\text { Glycerol and } \\
\text { Terminalia arjuna }\end{array}$ & Wrapped & Shelf-life was extended & [176] \\
\hline & Gelatin and carrageenan & Glycerol, lard and beeswax & Dipped & Weight loss was reduced & [177] \\
\hline
\end{tabular}


Table 6. em Cont.

\begin{tabular}{|c|c|c|c|c|c|}
\hline Food Application & Biopolymeric Matrix & Additives & Coating Technique & Positive Results & Reference \\
\hline \multicolumn{6}{|c|}{ Animal and Dairy Products } \\
\hline \multirow{3}{*}{ Chicken meat } & $\begin{array}{l}\text { Mango peel powder, } \\
\text { ciclodextrin and gelatin }\end{array}$ & $\begin{array}{c}\text { Glycerol and } \\
\text { polyvinyl alcohol }\end{array}$ & Wrapped & Shelf-life was extended & [178] \\
\hline & Gum Arabic & $\begin{array}{l}\text { Sorbitol, polyvinyl alcohol, } \\
\text { and Zanthoxylum rhetsa } \\
\text { extract }\end{array}$ & Wrapped & $\begin{array}{l}\text { Bioactive compounds were increased, and shelf-life } \\
\text { was extended }\end{array}$ & [179] \\
\hline & $\begin{array}{l}\text { Linear low-density } \\
\text { polyethylene }\end{array}$ & $\begin{array}{l}\text { Cinnamon essential oil and } \\
\text { silver-copper }\end{array}$ & Wrapped & $\begin{array}{l}\text { Antimicrobial capacity was increased, and shelf-life } \\
\text { was extended }\end{array}$ & [180] \\
\hline Butter & Low-density polyethylene & $\begin{array}{l}\text { Yerba mate and } \\
\text { carotenoid extracts }\end{array}$ & Wrapped & $\begin{array}{l}\text { Antimicrobial and antioxidant capacities were } \\
\text { increased, and shelf-life was extended }\end{array}$ & [181] \\
\hline Ham slices & $\begin{array}{c}\text { Cassava starch, chitosan and } \\
\text { gallic acid }\end{array}$ & Glycerol & Wrapped & Shelf-life was extended & [182] \\
\hline Fresh chicken breast & k-Carrageenan and chitosan & $\begin{array}{l}\text { Glycerol and oriental } \\
\text { mustard extract }\end{array}$ & Dipped & $\begin{array}{l}\text { Campylobacter jejuni was reduced and shelf-life } \\
\text { was extended }\end{array}$ & [183] \\
\hline Chicken nuggets & Alginate & Calcium chloride & Dipped & Microwave heating was improved & [184] \\
\hline Bream fish & Alginate & $\begin{array}{l}\text { Glycerol, vitamin } \mathrm{C} \text { and tea } \\
\text { polyphenols }\end{array}$ & Dipped & $\begin{array}{l}\text { Bacterial growth was inhibited, and sensory values } \\
\text { was enhanced }\end{array}$ & [185] \\
\hline Cheese & Galactomannan and chitosan & Glycerol, sorbitol and oil corn & Spread & Shelf-life was extended & [186] \\
\hline Poached turkey & $\begin{array}{l}\text { Alginate, pectin, } \\
\text { k-carrageenan, starch, and } \\
\text { xanthan gum }\end{array}$ & $\begin{array}{c}\text { Nisin, novagard CB1, } \\
\text { guardian NR100, sodium } \\
\text { lactate, sodium diacetate and } \\
\text { potassium sorbate }\end{array}$ & Dipped & Growth of Listeria monocytogenes was inhibited & [187] \\
\hline \multicolumn{6}{|c|}{ Bakery } \\
\hline \multirow{2}{*}{ Bread } & $\begin{array}{l}\text { Pectin, alginate and whey } \\
\text { protein }\end{array}$ & Glycerol and tween 20 & Sprayed & Moisture was decreased & [188] \\
\hline & Starch & Glycerol and $\varepsilon$-poly-L-lysine & Wrapped & Shelf-life was extended & [189] \\
\hline
\end{tabular}


According to the relevant findings reported by the research community, the maturity in fruits and vegetables and the mold and microbial growth can be delayed, preserving specific properties such as texture, freshness, vitamin C content and nutritional quality, as well as conferring new biological activities (e.g., antioxidant activity) depending on the types of bioactive solutes incorporated in the edible films and coatings. In animal and dairy products, the edible films and coatings allowed to maintain the bioactive components of the product itself and the sensory characteristics; the antimicrobial, antifungal and antioxidant activities, and shelf-life were also improved; while in bakery products, the moisture content decreased and the shelf-life increased.

\section{Concluding Remarks}

This review has compiled and analyzed the most recent studies about the application of edible films and coatings in a wide type of foods. Different types of materials have been used in manufacturing packing for the preservation and improvement of food products, emphasizing the bio-polymeric materials that have been used to form new barriers to directly protect the product. Furthermore, specific additives need to be incorporated to improve the physical characteristics and mechanical properties of the resulting packing. Today, as a current trend in the field, bioactive compounds and microorganisms (like probiotics) are added into sustainable packings to extend the functionality and nutrition of perishable and natural foods. The main application techniques that differentiate edible films from edible coatings were also shown, which influence together with the formation materials, the product quality, shelf-life, maturation, darkening effect, and the inhibition of pathogens.

To finalize, bio-packaging has demonstrated to meet the requirements for the protection of minimally processed foods and their use suggests an economic saving related to the loss of food due to natural maturation, managing to extend the shelf-life of the product. Depending on the biomaterials used and the types of biologically active compounds, specific properties, such as sensorial, physicochemical and nutritional characteristics, in coated products can be improved. However, there are still many biopolymers (e.g., zein) and additives with good characteristics to form edible films and coatings that have not been explored in detail, which may promise successful insights into the protection and preservation of food products.

Author Contributions: E.D.-M.: Conceptualization, data curation, formal analysis, writing-original draft preparation. R.C.-M.: writing-review and editing, validation. All authors have read and agreed to the published version of the manuscript.

Funding: This research received no external funding.

Acknowledgments: E. Díaz-Montes thanks to the Consejo Nacional de Ciencia y Tecnología (CONACyT No. 593731) for the scholarship granted. R. Castro-Muñoz acknowledges the School of Engineering and Science and the FEMSA-Biotechnology Center at Tecnológico de Monterrey for their support through the Bioprocess (0020209I13) Focus Group.

Conflicts of Interest: The authors declare no conflict of interest.

\section{References}

1. Davis, G.; Song, J.H. Biodegradable packaging based on raw materials from crops and their impact on waste management. Ind. Crops Prod. 2006, 23, 147-161. [CrossRef]

2. Raheem, D. Application of plastics and paper as food packaging materials-An overview. Emir. J. Food Agric. 2013, 25, 177-188. [CrossRef]

3. Kishimoto, A. New food packaging materials: An introduction. In Food Packaging; Kadoya, T., Ed.; Academic Press Inc.: San Diego, CA, USA, 1990; pp. 47-51. ISBN 0123935903.

4. SEMARNAT. Informe de la Situación del Medio Ambiente en México. Available online: https://apps1.semarnat.gob.mx: 8443/dgeia/informe15/tema/pdf/Informe15_completo.pdf (accessed on 2 September 2019).

5. SEMARNAT. Inventario de Residuos Sólidos de la Ciudad de México. Available online: https://sedema.cdmx.gob.mx/ programas/programa/residuos-solidos (accessed on 8 October 2019). 
6. Tavassoli-Kafrani, E.; Shekarchizadeh, H.; Masoudpour-Behabadi, M. Development of edible films and coatings from alginates and carrageenans. Carbohydr. Polym. 2016, 137, 360-374. [CrossRef] [PubMed]

7. Acevedo-Fani, A.; Soliva-Fortuny, R.; Martín-Belloso, O. Nanoemulsions as edible coatings. Curr. Opin. Food Sci. 2017, 15, 43-49. [CrossRef]

8. Tahir, H.E.; Xiaobo, Z.; Mahunu, G.K.; Arslan, M.; Abdalhai, M.; Zhihua, L. Recent developments in gum edible coating applications for fruits and vegetables preservation: A review. Carbohydr. Polym. 2019, 224, 115141. [CrossRef]

9. Marsh, K.; Bugusu, B. Food packaging-Roles, materials, and environmental issues. J. Food Sci. 2007, 72, 39-55. [CrossRef]

10. Siracusa, V.; Rocculi, P.; Romani, S.; Rosa, M.D. Biodegradable polymers for food packaging: A review. Trends Food Sci. Technol. 2008, 19, 634-643. [CrossRef]

11. Khwaldia, K.; Arab-Tehrany, E.; Desobry, S. Biopolymer coatings on paper packaging materials. Compr. Rev. Food Sci. Food Saf. 2010, 9, 82-91. [CrossRef]

12. Moran, F. Food packaging laws and regulation with particular emphasis on meat, poultry and fish. In Advances in Meat, Poultry and Seafood Packaging; Kerry, J.P., Ed.; Woodhead Publishing Limited: New Delhi, India, 2012; pp. 631-659. ISBN 9781845697518.

13. FDA. Guidance for Industry: Use of Recycled Plastics in Food Packaging (Chemistry Considerations). Available online: https: / / www.fda.gov/regulatory-information/search-fda-guidance-documents/guidance-industry-use-recycled-plasticsfood-packaging-chemistry-considerations (accessed on 8 October 2019).

14. ISO. ISO 18604. Packaging and the Environment-Material Recycling; ISO: Geneva, Switzerland, 2013; pp. 1-11.

15. INECC. La Cuenca de los Ríos Grijalva y Usumacinta. Available online: http://www2.inecc.gob.mx/publicaciones/libros/402/ cuencas.html (accessed on 8 October 2019).

16. Schäfer, A. EU Legislation. In Global Legislation for Food Packaging Materials; Rijik, R., Veraart, R., Eds.; Wiley-VCH Verlag GmbH \& Co. KGaA: Weinheim, Germany, 2010; pp. 1-26. ISBN 9783527630059.

17. Debeaufort, F.; Quezada-Gallo, J.-A.; Voilley, A. Edible films and coatings: Tomorrow's packagings: A review. Crit. Rev. Food Sci. Nutr. 1998, 38, 299-313. [CrossRef]

18. Embuscado, M.E.; Huber, K.C. Edible Films and Coatings for Food Applications; Springer Science+Business Media: New York, NY, USA, 2009; ISBN 9780387928234.

19. Montalvo, C.; López Malo, A.; Palou, E. Películas comestibles de proteína: Características, propiedades y aplicaciones. Temas Sel. Ing. Aliment. 2012, 6, 32-46.

20. Castro-Muñoz, R.; González-Valdez, J. New trends in biopolymer-based membranes for pervaporation. Molecules 2019, $24,3584$. [CrossRef] [PubMed]

21. Morales-Jiménez, M.; Gouveia, L.; Yañez-Fernandez, J.; Castro-Muñoz, J.; Barragan-Huerta, B.E. Microalgae-based biopolymer as a potential bioactive film. Coatings 2020, 10, 120. [CrossRef]

22. Guimarães, A.; Abrunhosa, L.; Pastrana, L.M.; Cerqueira, M.A. Edible films and coatings as carriers of living microorganisms: A new strategy towards biopreservation and healthier foods. Compr. Rev. Food Sci. Food Saf. 2018, 17, 594-614. [CrossRef]

23. Yai, H. Edible films and coatings: Characteristics and properties. Int. Food Res. J. 2008, 15, 237-248.

24. Guerrero Legarreta, I.; Rosmini, M.R.; Armenta, R.E. Tecnología de Productos de Origen Acuático; LIMUSA: Mexico City, Mexico, 2009; ISBN 9786070500862.

25. Falguera, V.; Quintero, J.P.; Jiménez, A.; Muñoz, J.A.; Ibarz, A. Edible films and coatings: Structures, active functions and trends in their use. Trends Food Sci. Technol. 2011, 22, 292-303. [CrossRef]

26. Salvia-Trujillo, L.; Soliva-Fortuny, R.; Rojas-Graü, M.A.; McClements, D.J.; Martín-Belloso, O. Edible nanoemulsions as carriers of active ingredients: A review. Annu. Rev. Food Sci. Technol. 2017, 8, 439-466. [CrossRef]

27. Sánchez Aldana, D.; Contreras-Esquivel, J.C.; Nevárez-Moorillón, G.V.; Aguilar, C.N. Caracterización de películas comestibles a base de extractos pécticos y aceite esencial de limón Mexicano. CYTA J. Food 2015, 13, 17-25. [CrossRef]

28. Kraśniewska, K.; Galus, S.; Gniewosz, M. Biopolymers-based materials containing silver nanoparticles as active packaging for food applications-A review. Int. J. Mol. Sci. 2020, 21, 698. [CrossRef] [PubMed]

29. Zhang, Y.; Han, J.; Liu, Z. Starch-based edible films. In Environmentally Compatible Food Packaging; Woodhead Publishing: Sawston, UK, 2008; pp. 108-136.

30. Castro-Muñoz, R.; Buera-González, J.; de la Iglesia, Ó.; Galiano, F.; Fíla, V.; Malankowska, M.; Rubio, C.; Figoli, A.; Téllez, C.; Coronas, J. Towards the dehydration of ethanol using pervaporation cross-linked poly(vinyl alcohol)/graphene oxide membranes. J. Membr. Sci. 2019, 582, 423-434. [CrossRef]

31. Castro-Muñoz, R.; Galiano, F.; Fíla, V.; Drioli, E.; Figoli, A. Matrimid ${ }^{\circledR} 5218$ dense membrane for the separation of azeotropic MeOH-MTBE mixtures by pervaporation. Sep. Purif. Technol. 2018, 199, 27-36. [CrossRef]

32. Kim, Y.T.; Min, B.; Kim, K.W. General characteristics of packaging materials for food system. In Innovations in Food Packaging; Han, J.H., Ed.; Elsevier Ltd.: San Diego, CA, USA, 2014; pp. 13-35. ISBN 9780123946010.

33. Salama, H.E.; Abdel Aziz, M.S.; Sabaa, M.W. Novel biodegradable and antibacterial edible films based on alginate and chitosan biguanidine hydrochloride. Int. J. Biol. Macromol. 2018, 116, 443-450. [CrossRef]

34. Khazaei, N.; Esmaiili, M.; Djomeh, Z.E.; Ghasemlou, M.; Jouki, M. Characterization of new biodegradable edible film made from basil seed (Ocimum basilicum L.) gum. Carbohydr. Polym. 2014, 102, 199-206. [CrossRef] [PubMed]

35. Martins, J.T.; Cerqueira, M.A.; Bourbon, A.I.; Pinheiro, A.C.; Souza, B.W.S.; Vicente, A.A. Synergistic effects between k-carrageenan and locust bean gum on physicochemical properties of edible films made thereof. Food Hydrocoll. 2012, 29, 280-289. [CrossRef] 
36. Pérez-Guzmán, C.J.; Castro-Muñoz, R. A review of zein as a potential biopolymer for tissue engineering and nanotechnological applications. Processes 2020, 8, 1376. [CrossRef]

37. Selby, H.H.; Whistler, R.L. Agar. In Industrial Gums-Polysaccharides and Their Derivatives; Whistler, R.L., BeMiller, J.N., Eds.; Academic Press Inc.: London, UK, 1993; pp. 87-103. ISBN 0127462538.

38. Enriquez, M.; Velasco, R.; Ortíz, V. Composición y procesamiento de películas biodegradables basadas en almidón. Biotecnol. Sect. Agropecu. Agroind. 2012, 10, 182-192.

39. Davidović, S.; Miljković, M.; Tomić, M.; Gordić, M.; Nešić, A.; Dimitrijević, S. Response surface methodology for optimisation of edible coatings based on dextran from Leuconostoc mesenteroides T3. Carbohydr. Polym. 2018, 184, 207-213. [CrossRef]

40. Constable, D. Guía del Principiante Para Hacer Velas, 1st ed.; Paidotribo, Ed.; Editorial Paidotribo: Barcelona, Spain, 2002; ISBN 8480196041.

41. Pérez, A.G. Química II-Un Enfoque Constructivista, 1st ed.; Quintanar, D.E., Ed.; Pearson Educación de México, S.A. de C.V.: Mexico City, Mexico, 2007; ISBN 9789702608448.

42. Williams, P.A.; Phillips, G.O. Introduction to food hydrocolloids. In Handbook of Hydrocolloids; Williams, P.A., Phillips, G.O., Eds.; Woodhead Publishing Limited: New Delhi, India, 2009; pp. 1-22. ISBN 9781439808207.

43. Milani, J.; Maleki, G. Hydrocolloid in food industry. Food Ind. Process. Methods Equip. 2012, 3, 17-38.

44. Shit, S.C.; Shah, P.M. Edible polymers: Challenges and opportunities. J. Polym. 2014, 2014, 1-13. [CrossRef]

45. Ganiari, S.; Choulitoudi, E.; Oreopoulou, V. Edible and active films and coatings as carriers of natural antioxidants for lipid food. Trends Food Sci. Technol. 2017, 68, 70-82. [CrossRef]

46. Wypych, G. Handbook of Plasticizers; ChamTec Published: New York, NY, USA, 2004; ISBN 1895198291.

47. Voet, D.; Voet, J.G.; Pratt, C. Fundamentos de Bioquímica—La Vida a Nivel Molecular, 2nd ed.; Editorial Medica Panamericana: Buenos Aires, Argentina, 2009; ISBN 9789500623148.

48. Veiga-Santos, P.; Oliveira, L.M.; Cereda, M.P.; Alves, A.J.; Scamparini, A.R.P. Mechanical properties, hydrophilicity and water activity of starch-gum films: Effect of additives and deacetylated xanthan gum. Food Hydrocoll. 2005, 19, 341-349. [CrossRef]

49. Xiao, Q.; Lim, L.T.; Tong, Q. Properties of pullulan-based blend films as affected by alginate content and relative humidity. Carbohydr. Polym. 2012, 87, 227-234. [CrossRef]

50. Lee, K.Y.; Mooney, D.J. Alginate: Properties and biomedical applications. Prog. Polym. Sci. 2012, 37, 106-126. [CrossRef] [PubMed]

51. Liu, J.; Liu, S.; Chen, Y.; Zhang, L.; Kan, J.; Jin, C. Physical, mechanical and antioxidant properties of chitosan films grafted with different hydroxybenzoic acids. Food Hydrocoll. 2017, 71, 176-186. [CrossRef]

52. Bautista-Baños, S.; Romanazzi, G.; Jiménez-Aparicio, A. Chitosan in the Preservation of Agritultural Commodities; Elsevier Inc.: Oxford, UK, 2016; ISBN 9780128027356.

53. Castro-Muñoz, R.; Gonzalez-Valdez, J.; Ahmad, Z. High-performance pervaporation chitosan-based membranes: New insights and perspectives. Rev. Chem. Eng. 2020, 1-16. [CrossRef]

54. Ahmad, M.; Nirmal, N.P.; Danish, M.; Chuprom, J.; Jafarzedeh, S. Characterisation of composite films fabricated from collagen/chitosan and collagen/soy protein isolate for food packaging applications. RSC Adv. 2016, 6, 82191-82204. [CrossRef]

55. Slimane, E.B.; Sadok, S. Collagen from cartilaginous fish by-products for a potential application in bioactive film composite. Mar. Drugs 2018, 16, 211. [CrossRef]

56. Moncayo-Martínez, D.C.; Buitrago-Hurtado, G.; Néstor, Y.; Algecira-Enciso, A. Películas comestibles a base de un biopolímero tipo dextrana Edible films based of dextran biopolymer. Agron. Colomb. 2016, 34, 107-109.

57. Beak, S.; Kim, H.; Song, K. Bin sea squirt shell protein and polylactic acid laminated films containing cinnamon bark essential oil. J. Food Sci. 2018, 83, 1896-1903. [CrossRef]

58. Abdelhedi, O.; Nasri, R.; Jridi, M.; Kchaou, H.; Nasreddine, B.; Karbowiak, T.; Debeaufort, F.; Nasri, M. Composite bioactive films based on smooth-hound viscera proteins and gelatin: Physicochemical characterization and antioxidant properties. Food Hydrocoll. 2017, 74, 176-186. [CrossRef]

59. Rangel-Marrón, M.; Mani-López, E.; Palou, E.; López-Malo, A. Effects of alginate-glycerol-citric acid concentrations on selected physical, mechanical, and barrier properties of papaya puree-based edible films and coatings, as evaluated by response surface methodology. Lwt 2019, 101, 83-91. [CrossRef]

60. Ghani, S.; Barzegar, H.; Noshad, M.; Hojjati, M. The preparation, characterization and in vitro application evaluation of soluble soybean polysaccharide films incorporated with cinnamon essential oil nanoemulsions. Int. J. Biol. Macromol. 2018, 112, 197-202. [CrossRef] [PubMed]

61. Zambrano-Zaragoza, M.L.; González-Reza, R.; Mendoza-Muñoz, N.; Miranda-Linares, V.; Bernal-Couoh, T.F.; Mendoza-Elvira, S.; Quintanar-Guerrero, D. Nanosystems in edible coatings: A novel strategy for food preservation. Int. J. Mol. Sci. $2018,19,705$. [CrossRef] [PubMed]

62. Silva, H.D.; Cerqueira, M.Â.; Vicente, A.A. Nanoemulsions for food applications: Development and characterization. Food Bioprocess Technol. 2012, 5, 854-867. [CrossRef]

63. Acosta, E. Bioavailability of nanoparticles in nutrient and nutraceutical delivery. Curr. Opin. Colloid Interface Sci. 2009, 14, 3-15. [CrossRef]

64. Marcuzzo, E.; Sensidoni, A.; Debeaufort, F.; Voilley, A. Encapsulation of aroma compounds in biopolymeric emulsion based edible films to control flavour release. Carbohydr. Polym. 2010, 80, 984-988. [CrossRef] 
65. Aytac, Z.; Ipek, S.; Durgun, E.; Tekinay, T.; Uyar, T. Antibacterial electrospun zein nanofibrous web encapsulating thymol/cyclodextrin-inclusion complex for food packaging. Food Chem. 2017, 233, 117-124. [CrossRef]

66. Ortiz, C.M.; Salgado, P.R.; Dufresne, A.; Mauri, A.N. Microfibrillated cellulose addition improved the physicochemical and bioactive properties of biodegradable films based on soy protein and clove essential oil. Food Hydrocoll. 2018, 79, 416-427. [CrossRef]

67. Abdel Aziz, M.S.; Salama, H.E.; Sabaa, M.W. Biobased alginate/castor oil edible films for active food packaging. Lwt 2018, 96, 455-460. [CrossRef]

68. Romano, N.; Tavera-Quiroz, M.J.; Bertola, N.; Mobili, P.; Pinotti, A.; Gómez-Zavaglia, A. Edible methylcellulose-based films containing fructo-oligosaccharides as vehicles for lactic acid bacteria. Food Res. Int. 2014, 64, 560-566. [CrossRef]

69. Odila Pereira, J.; Soares, J.; Sousa, S.; Madureira, A.R.; Gomes, A.; Pintado, M. Edible films as carrier for lactic acid bacteria. LWT Food Sci. Technol. 2016, 73, 543-550. [CrossRef]

70. Nayak, N.; Singh, H. Milk protein-Polysaccharide interactions in food systems. In Encyclopedia of Food Chemistry; Varelis, P., Melton, L., Shahidi, F., Eds.; Elsevier Inc.: Oxford, UK, 2019; pp. 431-438. ISBN 9780128140260.

71. Zhang, M.; Sun, C.; Li, Q. Interaction between the polysaccharides and proteins in semisolid food systems. In Encyclopedia of Food Chemistry; Varelis, P., Melton, L., Shahidi, F., Eds.; Elsevier Inc.: Oxford, UK, 2018; pp. 439-445. ISBN 9780128140260.

72. Altamirano-Fortoul, R.; Moreno-Terrazas, R.; Quezada-Gallo, A.; Rosell, C.M. Viability of some probiotic coatings in bread and its effect on the crust mechanical properties. Food Hydrocoll. 2012, 29, 166-174. [CrossRef]

73. Kris-Etherton, P.M.; Hecker, K.D.; Bonanome, A.; Coval, S.M.; Binkoski, A.E.; Hilpert, K.F.; Griel, A.E.; Etherton, T.D. Bioactive compounds in foods: Their role in the prevention of cardiovascular disease and cancer. Am. J. Med. 2002, 113, 71-88. [CrossRef]

74. Peterson, J.; Dwyer, J.; Stern, F.; England, N.; Mayer, J. Flavonoids: Dietary occurrence and Biochemical Activity. Nutr. Res. 1998, 18, 1995-2018. [CrossRef]

75. Bravo, L. Polyphenols: Chemistry, dietary sources, metabolism, and nutritional significance. Nutr. Rev. 1998, 56, 317-333. [CrossRef] [PubMed]

76. Castro-Muñoz, R.; Boczkaj, G.; Gontarek, E.; Cassano, A.; Fíla, V. Membrane technologies assisting plant-based and agro-food by-products processing: A comprehensive review. Trends Food Sci. Technol. 2020, 95, 219-232. [CrossRef]

77. Díaz-Montes, E.; Gutiérrez-Macías, P.; Orozco-Álvarez, C.; Castro-Muñoz, R. Fractionation of Stevia rebaudiana aqueous extracts via two-step ultrafiltration process: Towards rebaudioside a extraction. Food Bioprod. Process. 2020, 123, 111-122. [CrossRef]

78. Valencia-Arredondo, J.A.; Hernández-Bolio, G.I.; Cerón-Montes, G.I.; Castro-Muñoz, R.; Yáñez-Fernández, J. Enhanced process integration for the extraction, concentration and purification of di-acylated cyanidin from red cabbage. Sep. Purif. Technol. 2020, 238, 116492. [CrossRef]

79. Castro-Muñoz, R.; Yañez-Fernandez, J.; Fila, V. Phenolic compounds recovered from agro-food by-products using membrane technologies: An overview. Food Chem. 2016, 213, 753-762. [CrossRef]

80. Pérez-Vergara, L.D.; Cifuentes, M.T.; Franco, A.P.; Pérez-Cervera, C.E.; Andrade-Pizarro, R.D. Development and characterization of edible films based on native cassava starch, beeswax, and propolis. NFS J. 2020, 21, 39-49. [CrossRef]

81. Díaz-Galindo, E.P.; Nesic, A.; Cabrera-Barjas, G.; Mardones, C.; Von Baer, D.; Bautista-Baños, S.; Garcia, O.D. Physical-chemical evaluation of active food packaging material based on thermoplastic starch loaded with grape cane extract. Molecules 2020, 25, 1306. [CrossRef]

82. Khodaei, D.; Hamidi-Esfahani, Z.; Lacroix, M. Gelatin and low methoxyl pectin films containing probiotics: Film characterization and cell viability. Food Biosci. 2020, 36, 100660. [CrossRef]

83. Koc, B.; Akyuz, L.; Cakmak, Y.S.; Sargin, I.; Salaberria, A.M.; Labidi, J.; Ilk, S.; Cekic, F.O.; Akata, I.; Kaya, M. Production and characterization of chitosan-fungal extract films. Food Biosci. 2020, 35, 100545. [CrossRef]

84. Medeiros Silva, V.D.; Coutinho Macedo, M.C.; Rodrigues, C.G.; Neris dos Santos, A.; de Freitas e Loyola, A.C.; Fante, C.A. Biodegradable edible films of ripe banana peel and starch enriched with extract of Eriobotrya japonica leaves. Food Biosci. 2020, 38, 100750. [CrossRef]

85. Nogueira, G.F.; Fakhouri, F.M.; de Oliveira, R.A. Effect of incorporation of blackberry particles on the physicochemical properties of edible films of arrowroot starch. Dry. Technol. 2019, 37, 448-457. [CrossRef]

86. Rodsamran, P.; Sothornvit, R. Bioactive coconut protein concentrate films incorporated with antioxidant extract of mature coconut water. Food Hydrocoll. 2018, 79, 243-252. [CrossRef]

87. Rodsamran, P.; Sothornvit, R. Microencapsulation of Thai rice grass (O. sativa cv. Khao Dawk Mali 105) extract incorporated to form bioactive carboxymethyl cellulose edible film. Food Chem. 2018, 242, 239-246. [CrossRef]

88. Aparicio-Fernández, X.; Vega-Ahuatzin, A.; Ochoa-Velasco, C.E.; Cid-Pérez, S.; Hernández-Carranza, P.; Ávila-Sosa, R. Physical and antioxidant characterization of edible films added with red prickly pear (Opuntia ficus-indica L.) cv. San Martín peel and/or its aqueous extracts. Food Bioprocess Technol. 2018, 11, 368-379. [CrossRef]

89. Assis, R.Q.; Pagno, C.H.; Costa, T.M.H.; Flôres, S.H.; de Oliveira Rios, A. Synthesis of biodegradable films based on cassava starch containing free and nanoencapsulated $\beta$-carotene. Packag. Technol. Sci. 2018, 31, 157-166. [CrossRef]

90. Gómez-Guillén, M.C.; Montero, P.; López-Caballero, M.E.; Baccan, G.C.; Gómez-Estaca, J. Bioactive and technological functionality of a lipid extract from shrimp (L. vannamei) cephalothorax. LWT Food Sci. Technol. 2018, 89, 704-711. [CrossRef]

91. Wei, D.; Huo, W.; Li, G.; Xie, Q.; Jiang, Y. The combined effects of lysozyme and ascorbic acid on microstructure and properties of zein-based films. Chin. J. Chem. Eng. 2018, 26, 648-656. [CrossRef] 
92. Ounkaew, A.; Kasemsiri, P.; Kamwilaisak, K.; Saengprachatanarug, K.; Mongkolthanaruk, W.; Souvanh, M.; Pongsa, U.; Chindaprasirt, P. Polyvinyl alcohol (PVA)/starch bioactive packaging film enriched with antioxidants from spent coffee ground and citric acid. J. Polym. Environ. 2018, 26, 3762-3772. [CrossRef]

93. Cacicedo, M.L.; Islan, G.A.; Drachemberg, M.F.; Alvarez, V.A.; Bartel, L.C.; Bolzán, A.D.; Castro, G.R. Hybrid bacterial cellulosepectin films for delivery of bioactive molecules. New J. Chem. 2018, 42, 7457-7467. [CrossRef]

94. Hassan, E.A.; Fadel, S.M.; Hassan, M.L. Influence of TEMPO-oxidized NFC on the mechanical, barrier properties and nisin release of hydroxypropyl methylcellulose bioactive films. Int. J. Biol. Macromol. 2018, 113, 616-622. [CrossRef] [PubMed]

95. Silva, N.H.C.S.; Vilela, C.; Almeida, A.; Marrucho, I.M.; Freire, C.S.R. Pullulan-based nanocomposite films for functional food packaging: Exploiting lysozyme nanofibers as antibacterial and antioxidant reinforcing additives. Food Hydrocoll. 2018, 77, 921-930. [CrossRef]

96. Krepker, M.; Prinz-Setter, O.; Shemesh, R.; Vaxman, A.; Alperstein, D.; Segal, E. Antimicrobial carvacrol-containing polypropylene films: Composition, structure and function. Polymers 2018, 10, 79. [CrossRef]

97. Fernandez-Bats, I.; Di Pierro, P.; Villalonga-Santana, R.; Garcia-Almendarez, B.; Porta, R. Bioactive mesoporous silica nanocomposite films obtained from native and transglutaminase-crosslinked bitter vetch proteins. Food Hydrocoll. 2018, 82, 106-115. [CrossRef]

98. Hassan, M.M. Enhanced antimicrobial activity and reduced water absorption of chitosan films graft copolymerized with poly(acryloyloxy)ethyltrimethylammonium chloride. Int. J. Biol. Macromol. 2018, 118, 1685-1695. [CrossRef]

99. Alboofetileh, M.; Rezaei, M.; Hosseini, H.; Abdollahi, M. Antimicrobial activity of alginate/clay nanocomposite films enriched with essential oils against three common foodborne pathogens. Food Control 2014, 36, 1-7. [CrossRef]

100. Alvarez, M.V.; Ortega-Ramirez, L.A.; Gutierrez-Pacheco, M.M.; Bernal-Mercado, A.T.; Rodriguez-Garcia, I.; Gonzalez-Aguilar, G.A.; Ponce, A.; Moreira, M.D.R.; Roura, S.I.; Ayala-Zavala, J.F. Oregano essential oil-pectin edible films as anti-quorum sensing and food antimicrobial agents. Front. Microbiol. 2014, 5, 1-7. [CrossRef]

101. Gómez-Estaca, J.; López de Lacey, A.; López-Caballero, M.E.; Gómez-Guillén, M.C.; Montero, P. Biodegradable gelatin-chitosan films incorporated with essential oils as antimicrobial agents for fish preservation. Food Microbiol. 2010, 27, 889-896. [CrossRef]

102. Tarazona, A.; Gómez, J.V.; Gavara, R.; Mateo-Castro, R.; Gimeno-Adelantado, J.V.; Jiménez, M.; Mateo, E.M. Risk management of ochratoxigenic fungi and ochratoxin $\mathrm{A}$ in maize grains by bioactive $\mathrm{EVOH}$ films containing individual components of some essential oils. Int. J. Food Microbiol. 2018, 269, 107-119. [CrossRef] [PubMed]

103. Demitri, C.; Tarantino, A.S.; Moscatello, A.; De Benedictis, V.M.; Madaghiele, M.; Sannino, A.; Maffezzoli, A. Graphene reinforced Chitosan-Cinnamaldehyde derivatives films: Antifungal activity and mechanical properties. In Proceedings of the 1st Workshop on Nanotechnology in Instrumentation and Measurement (NANOFIM), Lecce, Italy, 24-25 July 2015; IEEE: Piscataway, NJ, USA, 2015; pp. 25-29.

104. Apak, R.; Güçlü, K.; Demirata, B.; Özyürek, M.; Çelik, S.E.; Bektaşoğlu, B.; Berker, K.I.; Özyurt, D. Comparative evaluation of various total antioxidant capacity assays applied to phenolic compounds with the CUPRAC assay. Molecules 2007, 12, 1496-1547. [CrossRef] [PubMed]

105. Burt, S. Essential oils: Their antibacterial properties and potential applications in foods-A review. Int. J. Food Microbiol. 2004, 94, 223-253. [CrossRef] [PubMed]

106. Uscátegui, Y.L.; Arévalo, F.R.; Díaz, L.E.; Cobo, M.I.; Valero, M.F. Microbial degradation, cytotoxicity and antibacterial activity of polyurethanes based on modified castor oil and polycaprolactone. J. Biomater. Sci. Polym. Ed. 2016, 27, 1860-1879. [CrossRef] [PubMed]

107. Choo, J.H.; Rukayadi, Y.; Hwang, J.K. Inhibition of bacterial quorum sensing by vanilla extract. Lett. Appl. Microbiol. 2006, 42, 637-641. [CrossRef] [PubMed]

108. Alboofetileh, M.; Rezaei, M.; Hosseini, H.; Abdollahi, M. Effect of montmorillonite clay and biopolymer concentration on the physical and mechanical properties of alginate nanocomposite films. J. Food Eng. 2013, 117, 26-33. [CrossRef]

109. Quintavalla, S.; Vicini, L. Antimicrobial food packaging in meat industry. Meat Sci. 2002, 62, 373-380. [CrossRef]

110. Van Long, N.N.; Joly, C.; Dantigny, P. Active packaging with antifungal activities. Int. J. Food Microbiol. 2016, 220, 73-90. [CrossRef]

111. Blackburn, C.W. Food Spoilage Microorganisms; Woodhead Publishing Limited: Boca Raton, FL, USA, 2006 ; ISBN 9781855739666.

112. Rawat, S. Food Spoilage: Microorganisms and their prevention. Pelagia Res. Libr. Asian J. Plant Sci. Res. $2015,5,47-56$.

113. Holzapfel, W. Advances in Fermented Foods and Beverages. Improving Quality, Technologies and Health Benefits; Elsevier Ltd.: Kidlington, Oxford, UK, 2015; ISBN 978-1-78242-015-6.

114. Pavli, F.; Kovaiou, I.; Apostolakopoulou, G.; Kapetanakou, A.; Skandamis, P.; Nychas, G.J.E.; Tassou, C.; Chorianopoulos, N. Alginate-based edible films delivering probiotic bacteria to sliced ham pretreated with high pressure processing. Int. J. Mol. Sci. 2017, 18, 1867. [CrossRef]

115. Marín, A.; Cháfer, M.; Atarés, L.; Chiralt, A.; Torres, R.; Usall, J.; Teixidó, N. Effect of different coating-forming agents on the efficacy of the biocontrol agent Candida sake CPA-1 for control of Botrytis cinerea on grapes. Biol. Control 2016, 96, 108-119. [CrossRef]

116. Parafati, L.; Vitale, A.; Restuccia, C.; Cirvilleri, G. The effect of locust bean gum (LBG)-based edible coatings carrying biocontrol yeasts against Penicillium digitatum and Penicillium italicum causal agents of postharvest decay of mandarin fruit. Food Microbiol. 2016, 58, 87-94. [CrossRef] [PubMed] 
117. Aloui, H.; Licciardello, F.; Khwaldia, K.; Hamdi, M.; Restuccia, C. Physical properties and antifungal activity of bioactive films containing Wickerhamomyces anomalus killer yeast and their application for preservation of oranges and control of postharvest green mold caused by Penicillium digitatum. Int. J. Food Microbiol. 2015, 200, 22-30. [CrossRef] [PubMed]

118. López de Lacey, A.M.; López-Caballero, M.E.; Montero, P. Agar films containing green tea extract and probiotic bacteria for extending fish shelf-life. LWT Food Sci. Technol. 2014, 55, 559-564. [CrossRef]

119. González-Forte, L.; Bruno, E.; Martino, M. Application of coating on dog biscuits for extended survival of probiotic bacteria. Anim. Feed Sci. Technol. 2014, 195, 76-84. [CrossRef]

120. Concha-Meyer, A.; Schöbitz, R.; Brito, C.; Fuentes, R. Lactic acid bacteria in an alginate film inhibit Listeria monocytogenes growth on smoked salmon. Food Control 2011, 22, 485-489. [CrossRef]

121. Fan, Y.; Xu, Y.; Wang, D.; Zhang, L.; Sun, J.; Sun, L.; Zhang, B. Effect of alginate coating combined with yeast antagonist on strawberry (Fragaria $\times$ ananassa) preservation quality. Postharvest Biol. Technol. 2009, 53, 84-90. [CrossRef]

122. Pavli, F.; Tassou, C.; Nychas, G.J.E.; Chorianopoulos, N. Probiotic incorporation in edible films and coatings: Bioactive solution for functional foods. Int. J. Mol. Sci. 2018, 19, 150. [CrossRef]

123. FAO/WHO. Guidelines for the Evaluation of Probiotics in Food. Available online: https://www.who.int/foodsafety/fs_ management/en/probiotic_guidelines.pdf (accessed on 1 October 2019).

124. Borriello, S.P.; Hammes, W.P.; Holzapfel, W.; Marteau, P.; Schrezenmeir, J.; Vaara, M.; Valtonen, V. Safety of probiotics that contain lactobacilli or bifidobacteria. Clin. Infect. Dis. 2003, 36, 775-780. [CrossRef]

125. Hammes, W.P.; Vogel, R.F. The genus Lactobacillus. In The Genera of Lactic Acid Bacteria; Springer: Boston, MA, USA, 1995; pp. $19-54$.

126. Gurtler, J.B.; Mai, T.L. Traditional preservatives-Organic acids. In Encyclopedia of Food Microbiology; Elsevier Ltd.: Amsterdam, The Netherlands, 2014; Volume 3, pp. 119-130. ISBN 9780123847331.

127. Gbassi, G.K.; Vandamme, T.; Ennahar, S.; Marchioni, E. Microencapsulation of Lactobacillus plantarum spp in an alginate matrix coated with whey proteins. Int. J. Food Microbiol. 2009, 129, 103-105. [CrossRef]

128. Noor, S.; Bhat, Z.F.; Kumar, S.; Mudiyanselage, R.J. Preservative effect of Asparagus racemosus: A novel additive for bioactive edible films for improved lipid oxidative stability and storage quality of meat products. Meat Sci. 2018, 139, 207-212. [CrossRef]

129. Marín, A.; Atarés, L.; Cháfer, M.; Chiralt, A. Properties of biopolymer dispersions and films used as carriers of the biocontrol agent Candida sake CPA-1. LWT Food Sci. Technol. 2017, 79, 60-69. [CrossRef]

130. Tavera-Quiroz, M.J.; Romano, N.; Mobili, P.; Pinotti, A.; Gómez-Zavaglia, A.; Bertola, N. Green apple baked snacks functionalized with edible coatings of methylcellulose containing Lactobacillus plantarum. J. Funct. Foods 2015, 16, 164-173. [CrossRef]

131. Soukoulis, C.; Yonekura, L.; Gan, H.H.; Behboudi-Jobbehdar, S.; Parmenter, C.; Fisk, I. Probiotic edible films as a new strategy for developing functional bakery products: The case of pan bread. Food Hydrocoll. 2014, 39, 231-242. [CrossRef] [PubMed]

132. Yinzhe, R.; Shaoying, Z. Effect of carboxymethyl cellulose and alginate coating combined with brewer yeast on postharvest grape preservation. ISRN Agron. 2013, 2013, 1-7. [CrossRef]

133. López De Lacey, A.M.; López-Caballero, M.E.; Gómez-Estaca, J.; Gómez-Guillén, M.C.; Montero, P. Functionality of Lactobacillus acidophilus and Bifidobacterium bifidum incorporated to edible coatings and films. Innov. Food Sci. Emerg. Technol. 2012, 16, 277-282. [CrossRef]

134. Soukoulis, C.; Behboudi-Jobbehdar, S.; Macnaughtan, W.; Parmenter, C.; Fisk, I.D. Stability of Lactobacillus rhamnosus GG incorporated in edible films: Impact of anionic biopolymers and whey protein concentrate. Food Hydrocoll. 2017, 70, 345-355. [CrossRef]

135. Kong, F.; Singh, R.P. Chemical deterioration and physical instability of foods and beverages. In Woodhead Publishing Series in Food Science, Technology and Nutrition; Subramaniam, P., Ed.; Elsevier Ltd.: Kidlington, Oxford, UK, 2016; pp. 43-76. ISBN 9780081004364.

136. Remize, F. Spore-forming bacteria. In The Microbiological Quality of Food: Foodborne Spoilers; Bevilacqua, A., Corbo, M.R., Sinigaglia, M., Eds.; Elsevier Ltd.: Amsterdam, The Netherlands, 2017; pp. 99-120. ISBN 9780081005033.

137. Roudaut, G.; Debeaufort, F. Moisture loss, gain and migration in foods and its impact on food quality. In Chemical Deterioration and Physical Instability of Food and Beverages; Skibsted, L.H., Risbo, J., Andersen, M.L., Eds.; Woodhead Publishing Limited: Boca Raton, FL, USA, 2010; pp. 143-185. ISBN 9781845694951.

138. Contreras Saavedra, S.; Ventura-Aguilar, R.I.; Bautista-Baños, S.; Barrera-Necha, L.L. Biodegradable chitosan coating for improving quality and controlling Alternaria alternata growth in figs. World J. Adv. Res. Rev. 2020, 7, 115-125. [CrossRef]

139. Hernández-López, G.; Ventura-Aguilar, R.I.; Correa-Pacheco, Z.N.; Bautista-Baños, S.; Barrera-Necha, L.L. Nanostructured chitosan edible coating loaded with $\alpha$-pinene for the preservation of the postharvest quality of Capsicum annuum L. and Alternaria alternata control. Int. J. Biol. Macromol. 2020, 165, 1881-1888. [CrossRef]

140. Hamzah, H.M.; Osman, A.; Tan, C.P.; Mohamad Ghazali, F. Carrageenan as an alternative coating for papaya (Carica papaya L. cv. Eksotika). Postharvest Biol. Technol. 2013, 75, 142-146. [CrossRef]

141. Alvarez, M.V.; Ponce, A.G.; Moreira, M.R. Influence of polysaccharide-based edible coatings as carriers of prebiotic fibers on quality attributes of ready-to-eat fresh blueberries. J. Sci. Food Agric. 2018, 98, 2587-2597. [CrossRef]

142. Duan, J.; Wu, R.; Strik, B.C.; Zhao, Y. Effect of edible coatings on the quality of fresh blueberries (Duke and Elliott) under commercial storage conditions. Postharvest Biol. Technol. 2011, 59, 71-79. [CrossRef] 
143. Ventura-Aguilar, R.I.; Bautista-Baños, S.; Flores-García, G.; Zavaleta-Avejar, L. Impact of chitosan based edible coatings functionalized with natural compounds on Colletotrichum fragariae development and the quality of strawberries. Food Chem. 2018, 262, 142-149. [CrossRef]

144. Velickova, E.; Winkelhausen, E.; Kuzmanova, S.; Alves, V.D.; Moldão-Martins, M. Impact of chitosan-beeswax edible coatings on the quality of fresh strawberries (Fragaria ananassa cv Camarosa) under commercial storage conditions. LWT Food Sci. Technol. 2013, 52, 80-92. [CrossRef]

145. Hajji, S.; Younes, I.; Affes, S.; Boufi, S.; Nasri, M. Optimization of the formulation of chitosan edible coatings supplemented with carotenoproteins and their use for extending strawberries postharvest life. Food Hydrocoll. 2018, 83, 375-392. [CrossRef]

146. del Carmen Martínez-González, M.; Bautista-Baños, S.; Correa-Pacheco, Z.N.; Corona-Rangel, M.L.; Ventura-Aguilar, R.I.; Del Río-García, J.C.; de Lorena Ramos-García, M. Effect of nanostructured chitosan/propolis coatings on the quality and antioxidant capacity of strawberries during storage. Coatings 2020, 10, 90. [CrossRef]

147. Bermúdez-Oria, A.; Rodríguez-Gutiérrez, G.; Vioque, B.; Rubio-Senent, F.; Fernández-Bolaños, J. Physical and functional properties of pectin-fish gelatin films containing the olive phenols hydroxytyrosol and 3,4-dihydroxyphenylglycol. Carbohydr. Polym. 2017, 178, 368-377. [CrossRef]

148. Thomas, A.B.; de Cássia Mirela Resende Nassur, R.; Vilas Boas, A.C.; de Oliveira Lima, L.C. Cassava starch edible coating incorporated with propolis on bioactive compounds in strawberries. Cienc. Agrotecnologia 2016, 40, 87-96. [CrossRef]

149. Vargas-Torres, A.; Becerra-Loza, A.S.; Sayago-Ayerdi, S.G.; Palma-Rodríguez, H.M.; de Lourdes García-Magaña, M.; MontalvoGonzález, E. Combined effect of the application of 1-MCP and different edible coatings on the fruit quality of jackfruit bulbs (Artocarpus heterophyllus Lam) during cold storage. Sci. Hortic. 2017, 214, 221-227. [CrossRef]

150. Allegra, A.; Inglese, P.; Sortino, G.; Settanni, L.; Todaro, A.; Liguori, G. The influence of Opuntia ficus-indica mucilage edible coating on the quality of "Hayward" kiwifruit slices. Postharvest Biol. Technol. 2016, 120, 45-51. [CrossRef]

151. Azevedo, V.M.; Dias, M.V.; de Siqueira Elias, H.H.; Fukushima, K.L.; Silva, E.K.; de Deus Souza Carneiro, J.; de Fátima Ferreira Soares, N.; Borges, S.V. Effect of whey protein isolate films incorporated with montmorillonite and citric acid on the preservation of fresh-cut apples. Food Res. Int. 2018, 107, 306-313. [CrossRef] [PubMed]

152. Koushesh Saba, M.; Sogvar, O.B. Combination of carboxymethyl cellulose-based coatings with calcium and ascorbic acid impacts in browning and quality of fresh-cut apples. LWT Food Sci. Technol. 2016, 66, 165-171. [CrossRef]

153. Sahraei Khosh Gardesh, A.; Badii, F.; Hashemi, M.; Ardakani, A.Y.; Maftoonazad, N.; Gorji, A.M. Effect of nanochitosan based coating on climacteric behavior and postharvest shelf-life extension of apple cv. Golab Kohanz. LWT Food Sci. Technol. 2016, 70, 33-40. [CrossRef]

154. Moreira, M.R.; Cassani, L.; Martín-Belloso, O.; Soliva-Fortuny, R. Effects of polysaccharide-based edible coatings enriched with dietary fiber on quality attributes of fresh-cut apples. J. Food Sci. Technol. 2015, 52, 7795-7805. [CrossRef]

155. Khan, M.K.I.; Cakmak, H.; Tavman, Ş.; Schutyser, M.; Schroën, K. Anti-browning and barrier properties of edible coatings prepared with electrospraying. Innov. Food Sci. Emerg. Technol. 2014, 25, 9-13. [CrossRef]

156. Ghavidel, R.A.; Davoodi, M.G.; Fahim, A.; Asl, A.; Tanoori, T.; Sheykholeslami, Z. Effect of selected edible coatings to extend shelf-life of fresh cut apples. Int. J. Agric. Crop Sci. 2013, 6, 1171-1178.

157. Chiumarelli, M.; Hubinger, M.D. Stability, solubility, mechanical and barrier properties of cassava starch-Carnauba wax edible coatings to preserve fresh-cut apples. Food Hydrocoll. 2012, 28, 59-67. [CrossRef]

158. El-anany, A.M.; Hassan, G.F.A.; Fm, R.-A. Effects oC edible coatings on the shelf-LiCe and quality oC anna apple (Malus domestica Borkh) during cold storage. J. Food Technol. 2009, 7, 5-11.

159. Fakhouri, F.M.; Martelli, S.M.; Caon, T.; Velasco, J.I.; Mei, L.H.I. Edible films and coatings based on starch/gelatin: Film properties and effect of coatings on quality of refrigerated Red Crimson grapes. Postharvest Biol. Technol. 2015, 109, 57-64. [CrossRef]

160. Azarakhsh, N.; Osman, A.; Ghazali, H.M.; Tan, C.P.; Mohd Adzahan, N. Lemongrass essential oil incorporated into alginate-based edible coating for shelf-life extension and quality retention of fresh-cut pineapple. Postharvest Biol. Technol. 2014, 88, 1-7. [CrossRef]

161. Robles-Sánchez, R.M.; Rojas-Graü, M.A.; Odriozola-Serrano, I.; González-Aguilar, G.; Martin-Belloso, O. Influence of alginatebased edible coating as carrier of antibrowning agents on bioactive compounds and antioxidant activity in fresh-cut Kent mangoes. LWT Food Sci. Technol. 2013, 50, 240-246. [CrossRef]

162. Sipahi, R.E.; Castell-Perez, M.E.; Moreira, R.G.; Gomes, C.; Castillo, A. Improved multilayered antimicrobial alginate-based edible coating extends the shelf life of fresh-cut watermelon (Citrullus lanatus). LWT Food Sci. Technol. 2013, 51, 9-15. [CrossRef]

163. Jafari, S.M.; Bahrami, I.; Dehnad, D.; Shahidi, S.A. The influence of nanocellulose coating on saffron quality during storage. Carbohydr. Polym. 2018, 181, 536-542. [CrossRef] [PubMed]

164. Licciardello, F.; Lombardo, S.; Rizzo, V.; Pitino, I.; Pandino, G.; Strano, M.G.; Muratore, G.; Restuccia, C.; Mauromicale, G. Integrated agronomical and technological approach for the quality maintenance of ready-to-fry potato sticks during refrigerated storage. Postharvest Biol. Technol. 2018, 136, 23-30. [CrossRef]

165. Aly, S.S.H.; Mohamed, E.N.; Abdou, E.S. Effect of edible coating on extending the shelf life and quality of fresh cut taro. Am. J. Food Technol. 2017, 12, 124-131. [CrossRef] 
166. Rodriguez-Garcia, I.; Cruz-Valenzuela, M.R.; Silva-Espinoza, B.A.; Gonzalez-Aguilar, G.A.; Moctezuma, E.; Gutierrez-Pacheco, M.M.; Tapia-Rodriguez, M.R.; Ortega-Ramirez, L.A.; Ayala-Zavala, J.F. Oregano (Lippia graveolens) essential oil added within pectin edible coatings prevents fungal decay and increases the antioxidant capacity of treated tomatoes. J. Sci. Food Agric. 2016, 96, 3772-3778. [CrossRef] [PubMed]

167. Dávila-Aviña, J.E.; Villa-Rodríguez, J.A.; Villegas-Ochoa, M.A.; Tortoledo-Ortiz, O.; Olivas, G.I.; Ayala-Zavala, J.F.; GonzálezAguilar, G.A. Effect of edible coatings on bioactive compounds and antioxidant capacity of tomatoes at different maturity stages. J. Food Sci. Technol. 2014, 51, 2706-2712. [CrossRef]

168. García, M.; Casariego, A.; Díaz, R.; Roblejo, L. Effect of edible chitosan/zeolite coating on tomatoes quality during refrigerated storage. Emir. J. Food Agric. 2014, 26, 238-246. [CrossRef]

169. Nandane, A.; Jain, R. Effect of composite edible coating on physicochemical properties of tomatoes stored at ambient conditions. Indian J. Adv. Eng. Technol. 2011, 2, 211-217.

170. Fagundes, C.; Palou, L.; Monteiro, A.R.; Pérez-Gago, M.B. Hydroxypropyl methylcellulose-beeswax edible coatings formulated with antifungal food additives to reduce alternaria black spot and maintain postharvest quality of cold-stored cherry tomatoes. Sci. Hortic. 2015, 193, 249-257. [CrossRef]

171. Fagundes, C.; Palou, L.; Monteiro, A.R.; Pérez-Gago, M.B. Effect of antifungal hydroxypropyl methylcellulose-beeswax edible coatings on gray mold development and quality attributes of cold-stored cherry tomato fruit. Postharvest Biol. Technol. 2014, 92, 1-8. [CrossRef]

172. Jiang, T.; Feng, L.; Wang, Y. Effect of alginate/nano-Ag coating on microbial and physicochemical characteristics of shiitake mushroom (Lentinus edodes) during cold storage. Food Chem. 2013, 141, 954-960. [CrossRef] [PubMed]

173. Takala, P.N.; Vu, K.D.; Salmieri, S.; Khan, R.A.; Lacroix, M. Antibacterial effect of biodegradable active packaging on the growth of Escherichia coli, Salmonella typhimurium and Listeria monocytogenes in fresh broccoli stored at $4{ }^{\circ} \mathrm{C}$. LWT Food Sci. Technol. 2013, 53, 499-506. [CrossRef]

174. Rhim, J.W.; Wang, L.F. Mechanical and water barrier properties of agar/k-carrageenan/konjac glucomannan ternary blend biohydrogel films. Carbohydr. Polym. 2013, 96, 71-81. [CrossRef]

175. Tzoumaki, M.V.; Biliaderis, C.G.; Vasilakakis, M. Impact of edible coatings and packaging on quality of white asparagus (Asparagus officinalis, L.) during cold storage. Food Chem. 2009, 117, 55-63. [CrossRef]

176. Kalem, I.K.; Bhat, Z.F.; Kumar, S.; Noor, S.; Desai, A. The effects of bioactive edible film containing Terminalia arjuna on the stability of some quality attributes of chevon sausages. Meat Sci. 2018, 140, 38-43. [CrossRef]

177. Tyburcy, A.; Kozyra, D. Effects of composite surface coating and pre-drying on the properties of kabanosy dry sausage. Meat Sci. 2010, 86, 405-410. [CrossRef]

178. Kanatt, S.R.; Chawla, S.P. Shelf life extension of chicken packed in active film developed with mango peel extract. J. Food Saf. 2017, 38, 1-12. [CrossRef]

179. Muppalla, S.R.; Chawla, S.P. Effect of Gum Arabic-polyvinyl alcohol films containing seed cover extract of Zanthoxylum rhetsa on shelf life of refrigerated ground chicken meat. J. Food Saf. 2018, 38, 1-10. [CrossRef]

180. Ahmed, J.; Mulla, M.; Arfat, Y.A.; Bher, A.; Jacob, H.; Auras, R. Compression molded LLDPE films loaded with bimetallic (Ag-Cu) nanoparticles and cinnamon essential oil for chicken meat packaging applications. Lwt 2018, 93, 329-338. [CrossRef]

181. Moura, L.E.; de Souza, C.O.; de Oliveira, E.A.S.; Lemos, P.V.F.; Druzian, J.I. Bioactive efficacy of low-density polyethylene films with natural additives. J. Appl. Polym. Sci. 2018, 135, 46461. [CrossRef]

182. Zhao, Y.; Teixeira, J.S.; Gänzle, M.M.; Saldaña, M.D.A. Development of antimicrobial films based on cassava starch, chitosan and gallic acid using subcritical water technology. J. Supercrit. Fluids 2018, 137, 101-110. [CrossRef]

183. Olaimat, A.N.; Fang, Y.; Holley, R.A. Inhibition of Campylobacter jejuni on fresh chicken breasts by k-carrageenan/chitosan-based coatings containing allyl isothiocyanate or deodorized oriental mustard extract. Int. J. Food Microbiol. 2014, 187, 77-82. [CrossRef] [PubMed]

184. Albert, A.; Salvador, A.; Fiszman, S.M. A film of alginate plus salt as an edible susceptor in microwaveable food. Food Hydrocoll. 2012, 27, 421-426. [CrossRef]

185. Song, Y.; Liu, L.; Shen, H.; You, J.; Luo, Y. Effect of sodium alginate-based edible coating containing different anti-oxidants on quality and shelf life of refrigerated bream (Megalobrama amblycephala). Food Control 2011, 22, 608-615. [CrossRef]

186. Cerqueira, M.A.; Sousa-Gallagher, M.J.; Macedo, I.; Rodriguez-Aguilera, R.; Souza, B.W.S.; Teixeira, J.A.; Vicente, A.A. Use of galactomannan edible coating application and storage temperature for prolonging shelf-life of "Regional" cheese. J. Food Eng. 2010, 97, 87-94. [CrossRef]

187. Juck, G.; Neetoo, H.; Chen, H. Application of an active alginate coating to control the growth of Listeria monocytogenes on poached and deli turkey products. Int. J. Food Microbiol. 2010, 142, 302-308. [CrossRef]

188. Nallan Chakravartula, S.S.; Cevoli, C.; Balestra, F.; Fabbri, A.; Dalla Rosa, M. Evaluation of drying of edible coating on bread using NIR spectroscopy. J. Food Eng. 2019, 240, 29-37. [CrossRef]

189. Luz, C.; Calpe, J.; Saladino, F.; Luciano, F.B.; Fernandez-Franzón, M.; Mañes, J.; Meca, G. Antimicrobial packaging based on $\varepsilon$-polylysine bioactive film for the control of mycotoxigenic fungi in vitro and in bread. J. Food Process. Preserv. 2018, 42, 1-6. [CrossRef] 